\title{
Review of factors influencing social learning within participatory environmental governance
}

\author{
Anna Ernst ${ }^{1,2}$
}

\begin{abstract}
Participatory environmental governance might foster social learning, which could lead to the necessary process of social change toward sustainable development. However, current research is still largely inconclusive regarding how and under what conditions participatory environmental governance enhances social learning. Here, my aim is to improve the understanding of how participatory framework conditions influence social learning and to provide a reference point for future research. I conducted a narrative literature review, consolidating multifaceted empirical research to identify and discuss factors that explain social learning. The literature comprised 72 publications and resulted in 11 factors that are highly interconnected. These interconnections denote the causes of social learning. However, some factors such as the personal characteristics of participants have only been marginally investigated. In addition, although cognitive change is theoretically an essential element of social learning, it has rarely been investigated in the reviewed studies. Knowledge acquisition was assessed most often, but does not always lead to cognitive change. A research gap was identified between what is theoretically discussed as social learning processes and what is empirically analyzed. This review therefore presents the state of knowledge about how participatory environmental governance fosters social learning and suggests future research.
\end{abstract}

Key Words: environmental governance; evaluating participation; participation; review; social learning

\section{INTRODUCTION}

Participatory environmental governance has received much attention from scientists and decision makers because of its potential to improve decision making. Participatory environmental governance refers to the processes and structures that, alongside policy makers, involve actors from civil society, administration, and business in deciding and managing (Newig et al. 2018) environment-related issues such as water management, energy infrastructure, and nature conservation. Social learning is a major area of interest within the field of participatory environmental governance (Reed et al. 2010, Siebenhüner et al. 2016). Social learning is understood here as an analytical concept that can be used to investigate normative, substantive, and instrumental participatory mechanisms (Fiorino 1990), and thus, provides a valuable research object. It helps to explore "knowledge claims between the parties in a process, while also exploring different values and ways of seeing the world" (Burgess and Clark 2009:183). Social learning is a collective communication process (Muro and Jeffrey 2008) of acquiring knowledge, making sense and abstracting meaning, and disseminating knowledge (Heikkila and Gerlak 2013). The process takes place in a social setting and leads to relational, cognitive, and technical change (Muro and Jeffrey 2012). Such a social setting is participatory environmental governance, and thus, social learning is understood here as an outcome of participation processes. Further outcomes (the final result or effect) of participation processes can be environmental (e.g., improved habitat or water quality) or socioeconomic (e.g., changes of institutions; Conley and Moote 2003). It is assumed that social learning through participatory environmental governance could induce the necessary social change process toward sustainable development.

Despite increasing research on participation in environmental governance, there is still a lack of understanding about how and under what conditions participation leads to improved outcomes
(Heikkila and Gerlak 2013, Newig et al. 2018). In their recent systematic metareview, Gerlak et al. (2018) concluded that the participatory contexts in which social learning takes place have been insufficiently studied. This conclusion corroborates previous research that found that, "despite high expectations, social learning processes in sustainability appraisals are poorly conceptualized and empirically understudied" (Garmendia and Stagl 2010:1712). Research has been conducted on participatory environmental governance, but the findings are still largely inconclusive (von Korff et al. 2012). There is not only a lack of empirical evidence analyzing whether participation promotes social learning, but also a scarcity of profound analytical concepts guiding such empirical analyses.

Here, I perform a narrative review to extend the findings of the systematic reviews of Siebenhüner et al. (2016) and Gerlak et al. (2018), analyzing the issue of social learning by applying metaanalyses. This qualitative review of 72 publications supports empirical findings from a range of different research efforts and aims to identify a comprehensive set of factors that explain social learning within the scope of participatory environmental governance. A clear definition and analysis of factors influencing social learning offers a reference point for future empirical research. The findings can be used in the evaluation of participation processes, which, in addition to precise and unbiased elaboration, requires a clear definition of the indicators measured. Furthermore, the results point to research gaps and provide a better understanding of the interdependence of the participatory setting (cause) and the social learning outcome (effect). Therefore, this study makes an original contribution to the scientific debate on how participatory governance can improve environmental outcomes and promote sustainable development.

I have structured the paper as follows. First, I explain the selection of studies reviewed. In the narrative review of literature, I define 
each factor identified and then discuss existing empirical findings assessing social learning within the scope of participatory environmental governance. I then discuss the findings in a wider sense and present the interdependencies identified between causes and effects. Finally, I end with conclusions about the current state of research and point to research gaps.

\section{REVIEW APPROACH}

In the narrative literature review, I examine existing empirical findings and identify important factors that influence social learning within the context of participatory environmental governance. In contrast to systematic metareviews, which usually provide quantitative syntheses of existing research findings (Roberts et al. 2006), narrative reviews are rather unsystematic, comprehensive, and descriptive syntheses of already published scientific results (Green et al. 2006). They represent a valuable method of linking studies from different topics for the purpose of establishing interconnections and interpreting the results of single case studies in a broader sense (Baumeister and Leary 1997). This process is important for analyzing the interconnection of participation and social learning.

I defined some criteria for excluding or including literature before the literature search was undertaken. To develop a theory that includes possible factors influencing social learning, I reviewed findings from studies that used multiple research methods. Waylen et al. (2015) emphasize that there is a lack of research on "imperfect participation processes" and that the implications of various aspects of these processes, such as different expectations of politicians and participants, are therefore insufficiently understood. In addition, a diverse range of cultural and political systems must be considered in the case of participatory environmental governance. My review includes various research designs and studies from different countries or regions. Because of the large, and steadily increasing, number of findings in participation research (von Korff et al. 2012), I only focused on studies in the field of environmental governance. Environmental governance is understood to be the setting of rules, decisionmaking procedures, and activities that serve to define social practices and guide the interactions of actors in practices (Young 1997) that have serious environmental impacts or center around environmental issues (Coenen 2009). The concentrated focus of my study is not only necessary for minimizing the amount of literature but also for comparing specific factors, meaning that similar contextual conditions are necessary. Furthermore, I chose only empirical studies assessing social learning in participatory environmental governance because I compared theoretical assumptions with existing empirical evidence. However, most empirical studies assessing social learning are explorative or do not define precisely factors that influence social learning. This reason is why I chose literature from participation research such as reviews, theoretical research, or empirical papers with strong theoretical foundation to define each factor. To ensure the quality and currentness of data in the literature reviewed, I only considered literature published in scientific journals, as a book, or as book chapters between 1990 and 2018. Definitions of participation and social learning, which further guided the selection of literature, are provided in the following three paragraphs.

As with many frequently used terms, there is no common understanding or definition of the term participation. The terms public participation, political participation, citizen participation, collaboration, and citizen involvement or engagement are often applied synonymously (Schroeter et al. 2016), and are summarized here using the term participation. I provide a definition and understanding of the term participation, but without a wholesale depiction of the scientific debate. The normative understanding of participation derives from deliberative theory, which focuses on the considered weighing of options through applied logic and reason (Renn 2006). This understanding includes the actors involved in gaining influence over the output and outcome of the decision-making process (Rowe and Frewer 2000). In contrast to traditional, sovereign, decision-making approaches, participation aims at involving both experts and professional politicians as well as lay people and organizations that are not legally responsible for making socially relevant decisions (Renn 2005). Participation is discussed as having numerous consequences such as "promoting the development of individual capacities, building community, and legitimating the regime" (Verba et al. 1995:12). Here, I use the term "participation" in its broadest sense to consider as many aspects of participation as possible, deriving, as much as possible, a holistic list of factors that influence social learning. Therefore, participation is defined here as a process involving citizens, experts, state or governmental actors, and other stakeholders that influence decision making at any stage of environmental governance. This definition does not include simple voting procedures for electing officials or for referenda (Beierle and Cayford 2002).

Siebenhüner et al.'s (2016) review of social learning shows that understandings and definitions of social learning vary greatly. It demonstrates that social learning is used as an analytical concept to examine social processes or is applied as a governance instrument. In addition, various goals and aims are associated with social learning, such as capacity building, knowledge integration, adaptive management (Westberg and Polk 2016), and change of governance systems (Armitage et al. 2008) or whole societies (Siebenhüner et al. 2016). Reed et al.'s (2010) review of social learning further underlines that social learning is defined in multiple, overlapping ways, and that some concepts lack a proper distinction between casual factors explaining social learning and elements and process dynamics of social learning. As Muro (2008) argues, there is no right or wrong definition of social learning, but the diverse range of learning concepts is more complementary than competitive. Therefore, research referring to theoretical concepts similar or closely related to social learning, such as transformative learning (Wilner et al. 2012); cognitive, normative, and relational learning (Baird et al. 2014); collaborative learning (Leach et al. 2014, Elbakidze et al. 2015); policy learning (Huitema et al. 2010); mutual learning (Wiek 2007); multidirectional learning (Roldán 2017); knowledge integration (Berman 2017); and coproduction of knowledge (Pohl et al. 2010, Edelenbos et al. 2011), are considered useful sources for investigating factors that influence social learning within participation processes. Such research complements the review.

Here, I discuss social learning as an analytical concept to investigate environmental governance and, more generally, transformation processes. Following Reed et al.'s (2010) definition, social learning consists not only of the elements of acquiring new information and experiences, and inducing change in the individuals involved, but must take place through social 
interactions; change should go beyond the individual to affect wider social units. Change is understood as the assimilation or accommodation (Muro 2008) of individual cognition, values, and perceptions, which is not to be mistaken with establishing proenvironmental positions and behavior (Caspersen et al. 2017). Such a change process can have multiple dimensions such as relational (e.g., improved sense of community), cognitive (e.g., change of perspectives), and technical (e.g., communication skills), and is dynamic (Muro and Jeffrey 2012). The learning phases such as acquiring knowledge, making sense and abstracting meaning, and disseminating knowledge (Heikkila and Gerlak 2013) do not necessarily emerge as a linear development. This definition makes a clear distinction between social learning and participation: social learning occurs through participation, and thus, it is assumed that the conditions of participation processes explain social learning.

I obtained literature through multiple search methods, including electronic searching of search engines, snowballing, and identification of studies through ResearchGate (https://www. researchgate.net/) and mailing lists. Electronic searches using the terms "social learning", "learning", "participation", "collaboration", and "consultation" were performed in the Web of Science, Google Scholar, and Scopus databases. In addition, continuous literature searches were conducted through a Google Scholar alert using the terms in the title "participation or consultation or collaborative", and two Scopus search alerts using the keywords "social learning" and "participation or consultation or collaborative". Most suitable literature, however, was detected by conducting a backward snowball approach to identify published empirical findings by searching the references of articles, which continued as the study proceeded. Based on the described selection criteria, 48 publications assessing social learning were identified, and 24 theory-driven publications in participation research were considered for the conceptual part and provide the foundation of the narrative literature review (Appendix 1).

\section{FACTORS INFLUENCING SOCIAL LEARNING}

Here, I review empirical studies assessing social learning within the framework of environmental governance, examining possible factors that influence social learning. Based on the assumption that social learning occurs through participation processes, I define and discuss factors describing participation processes. Similar to the literature evaluating participatory environmental governance (Carr et al. 2012), I distinguished three generic categories that cluster the identified factors and structure the literature review. The "participation process characteristics" category comprises factors describing process characteristics such as participation format or diversity of participants. "Normative process factors" describe desirable and often theory-driven factors. "Intermediate process outcomes" include factors that evolve during the course of participation and denote short-term effects of participation such as trust and conflict resolution. In each section for each factor, I begin by defining and conceptualizing each term, and then review the empirical literature.

\section{Participation process characteristics}

\section{Participation format}

A participation format is the method and organization structure that characterizes a participation process and describes the intensity of communication or dialogue. For example, public meetings and advisory committees provide different opportunities to participate (Beierle and Cayford 2002) and can be distinguished by the extent to which the public can share in collective decision making, structure of dialogue, and the time period of participation (Fiorino 1990). Coenen et al. (1998) claim that different participation formats generate different outcomes of participation processes. However, there is still debate about which are the best participation strategies.

The review of social learning literature provides inconclusive findings about the desired intensity of collective dialogue and communication. Berman (2017) focuses on the integration of local knowledge within participation processes and argues that participation formats that are dialogic, take place over time, and are unmediated represent the best ways of finding alternative solutions and promoting consensus, understanding, and the dissemination of knowledge. Muro and Jeffrey (2012) found that face-to-face and dialogic processes seem to promote social learning to a greater extent than do less intensive participation processes, but that less intensive participation also resulted in cognitive change.

Leach et al.'s(2014) findings suggest that "extended engagement", which means that participants engaged multiple times in a process, promotes social learning. This kind of repeated contact might reduce conflicts because time is taken to understand the perspectives of others (Webler et al. 1995). This idea is why scholars argue for a sufficient process duration and early involvement (Tippett et al. 2005). Similar findings suggest that the number of meetings and activities complementary to plenary discussions, such as field trips, enhance social learning (Petts 2006, Mostert et al. 2007). Beers et al. (2016) further indicate that different forms of interaction offer different potential for generating learning outcomes. In particular, participation resulted in learning when participants were able to question each other's positions and estimate the validity of proposed actions. Furthermore, the venue where the interaction takes place might also influence learning processes. Webler et al. (1995) indicate that a familiar atmosphere such as a pub or restaurant relaxed participants, thereby promoting a sense of collegiality.

In contrast, Cundill's (2010) findings suggest that identical participation formats might yield different learning outcomes. Her study indicates that factors such as participation format, process organization, and knowledge integration do not influence social learning directly but rather via normative process factors or intermediate process outcomes such as procedural fairness and trust.

\section{Access to information}

Access to information relates to access to external scientific and technical resources (Beierle 2002, Carr et al. 2012) and to relevant knowledge that refers to the decision (Schroeter et al. 2016). Beierle (2002) demonstrated that insufficient access to information can prevent effective participation in decision making.

Van de Kerkhof and Wieczorek (2005) suggest that the information provided in the process should be of scientific quality but communicated in a way that is comprehensible and accessible, which also makes uncertainties and controversies explicit to increase participants' competence to deliberate and make argued 
choices. Information ought to be communicated understandably for the participants, and access to further information must be guaranteed, for example, the collection, organization, and provision of information from the Internet (Mostert et al. 2007). Access to information should be ensured, providing sufficient opportunities and freedom to shape the learning process and a certain degree of ownership (van de Kerkhof and Wieczorek 2005).

\section{Facilitation}

Facilitation refers to the mediation and structuring of discussions as well as the balancing of contributions and the creation of opportunities for equal participation (Palm and Thoresson 2014, Ernst et al. 2017). To manage the dominance of a few participants and power imbalances, which might limit equal participation opportunities and create biased outcomes, skilled facilitation is seen as an important driver of successful participation by Leach and Pelkey (2001) and Reed (2008).

Skilled facilitation is seen as a key factor fostering social learning by Tippett et al. (2005), van de Kerkhof and Wieczorek (2005), and Petts (2006). Some studies indicate that facilitation of the participation processes is critical for sustaining the relationships that lead to increased trust and legitimacy (Edelenbos et al. 2011, Podestá et al. 2013). Pohl et al. (2010) consider a trustworthy relationship as essential for identifying and acknowledging both limitations and potentials of each knowledge type and perspective. However, Wiek (2007) notes that confounded agendas, different perceptions of appropriate data acquisition, reluctance to face exposure, and coexisting values can hamper the process and might make some knowledge types or perspectives perceived as more relevant or legitimate than others. Therefore, Wiek (2007:57) argues that appropriate facilitation should mediate, structure discussion, and balance contributions in a way to "cope with a great number of social aspects such as communication technology and virtuality, team size and structure (power, roles, possibility of participation), which could greatly influence the knowledge-generation performance of the collaborating agents." Furthermore, it is suggested that facilitation must be independent (van de Kerkhof and Wieczorek 2005) because defending one's own interests prevents neutral facilitation (Mostert et al. 2007). Facilitation aiming to enable participation, and thus, social learning, ought to overcome participation barriers. Therefore, facilitators should choose a venue that is in close proximity to the target group and provide financial and other support to stakeholders requiring assistance (Mostert et al. 2007).

\section{Diversity of participants}

The diversity of participants, meaning the representation of interests, values, and knowledge, influences the outcomes of participation processes. Although the participants should represent a sample of the population of affected public, a relative distribution of views and interests should be pursued (Rowe and Frewer 2000). Furthermore, Koontz and Johnson (2004) found that the number and balance of stakeholder types participating influence the content of discourse and the outcome.

Multiple actors must be included in the participation process because social learning aims to integrate different knowledge types (Brown et al. 2005). According to Knoepfel and KisslingNäf (1998), the social learning process is influenced by the number and type of participants. However, van der Wal et al. (2014) argue that an increase in participants does not necessarily improve learning conditions, but rather that a balanced stakeholder selection is key. Mostert et al. (2007) showed that a lack of participant selection might lead to the absence of important stakeholders and thus reduce the legitimacy of the participation process and opportunities for social learning. The selection of participants should not only be guided by the identification of all relevant perspectives and interests, but should also consider issues of power and create a balance of power, which is viewed as a prerequisite for social learning (Mostert et al. 2007). van de Kerkhof and Wieczorek (2005) conclude that participants should be selected by an independent facilitator. They argue that a balance between homogeneity and heterogeneity needs to be achieved: heterogeneity to ensure alternative viewpoints and ideas, and homogeneity to provide a common ground for discussion and action. However, van de Kerkhof and Wieczorek (2005) acknowledge that this may be hindered by people's lack of motivation to participate in the first place.

\section{Participants' characteristics}

Some studies indicate that the participants' characteristics influence participation processes. Participants' characteristics are manifold and, next to gender and age, behavioral patterns such as civic attitude or the political engagement of participants (Parés et al. 2015) are summarized in this term. Furthermore, the creativity, willingness to cooperate, commitment (Leach and Pelkey 2001), and competence (skills, abilities, knowledge; Webler 1995, Beierle and Cayford 2002) of individuals are important participant characteristics shaping participation processes.

In contrast to van der Wal et al. (2014), Leach et al. (2014) consider the characteristics of the individual participating as important features that influence the learning outcome. Tippett et al. (2005) highlight that the different mental models and framings of the process by participants, based on the reasons for participating, expertise and knowledge, previous experiences, interests, and perception of the problem, need to be recognized to encourage change. It is essential that the participants involved are open to questioning their own underlying assumptions, values, habits, and actions. Squires and Renn (2011) found that social learning is influenced by participants' individual degree of knowledge of the respective topic. In addition, Egunyu and Reed (2015) suggest that learning activities and outcomes differ for men and women because norms and traditions about the place of women and men in society hinder engagement in certain topics and participation in general. This situation leads to fewer learning opportunities and possibilities for getting to know unfamiliar topics. Furthermore, established social norms as well as different levels of education and literacy might limit opportunities for learning and influence.

\section{Context}

A clear definition of what "context" entails is difficult because the characteristics defining context are almost endless (O'Toole and Meier 2015). Context consists of the features of the type of issue, pre-existing relationships, and the institutional setting (Beierle and Cayford 2002). Furthermore, pre-existing social and cultural contexts are important features influencing participation (Peterson et al. 2010) and describing the given situation.

A comparative case study conducted by Cundill (2010) found that variation in social learning might be explained by preexisting institutions. Hierarchical institutional structures and cultural 
frameworks may provide insufficient support for participation and, therefore, social learning (Tippett et al. 2005, Benson et al. 2016). Giebels et al.'s (2016) findings indicate that governance approaches to knowledge generation need to match the context. They found that factors such as knowledge capacity and conflict are important contextual factors influencing learning processes. Their approach builds on the findings of Jennings and Hall (2012), which indicate that the perceived availability, relevance, and credibility of (scientific) knowledge has an effect on the acting agency's readiness to engage in dialogue. However, crises such as environmental disasters (floods, etc.) might also increase general awareness and overcome institutional barriers. They create pressure to act and they lead to increased citizen demand to become part of the decision and planning process (Mostert et al. 2007), which might trigger social learning (Siebenhüner et al. 2016).

\section{Normative process factors}

\section{Procedural fairness}

The factor of fairness (also justice) can be understood in multiple ways within the context of participation processes and is often not clearly defined in the reviewed literature. However, the reviewed literature most frequently addresses aspects of procedural fairness when considering fairness or justice. Issues regarding distributive fairness are discussed within the terms "effectiveness", "efficiency", and "satisfaction". Following Webler (1995:47), an ideal participation process should realize popular sovereignty and political equality so that participants "must presume each other to have equal chances to effect the formulation of the argument." Procedural fairness indicates whether people's ability to attend, initiate, and participate in discourse as well as contribute to decision making (Webler and Tuler 2000) comply with normative assumptions and expectations about fairness. Furthermore, Schroeter et al. (2016) stress that procedural fairness is a "subjective impression" of the process.

Webler et al. (1995) and Leach et al. (2014) found that a participatory process characterized by equal participation in which participants feel that they are heard and treated fairly enhances social learning. Controversies exist on whether to establish an open dialogue that can be attended by everyone, or to limit groups of participants (van de Kerkhof and Wieczorek 2005). Furthermore, Leach and Sabatier (2005) provide evidence that fair processes are not only highly associated with social learning but also with trust among stakeholders. Van de Kerkhof and Wieczorek (2005) see the facilitator as being responsible for ensuring a fair process. However, very few empirical studies analyze issues of procedural fairness.

\section{Effectiveness, efficiency, and satisfaction}

In contrast with procedural fairness, which refers to the process, the factors effectiveness, efficiency, and satisfaction relate to the (perceived) output and outcome of participation. The effectiveness of participation processes measures the impact of a participation process (Schroeter et al. 2016). Efficiency judges the outcome of the process in relation to the resources used (Ernst et al. 2017) and is closely related to what Carr et al. (2012) refer to as cost-effectiveness. However, some studies emphasize that the participants' perception of their own effect on the participation process should be measured instead of effectiveness. Respondents may subconsciously overestimate the effectiveness of the participation process they were involved in "to avoid the emotional discomfort" (Leach et al. 2002:665). Furthermore, satisfaction with the process does not equate to being totally content with the results (Parés et al. 2015, Schroeter et al. 2016). Satisfaction relates to one's own participation and whether it was satisfying. This concept differs from the perception of procedural fairness, which refers to whether the participation opportunities were fair for everyone.

Koontz's (2014) findings from a comparative case study in Germany and USA provide evidence that greater social learning is positively associated with participants' greater process control and perceived individual efficacy. It is suggested that the capacity of individuals, or faith in one's own ability to engage (meaningfully) in the process, can enhance learning outcomes (Webler et al. 1995, Kumler and Lemos 2008, Natarajan 2017). The appropriate facilitation and communication of information might help to overcome limited confidence in one's own abilities to participate (Natarajan 2017). No literature was found that analyzes whether efficiency or effectiveness influence social learning.

\section{Legitimacy}

Participation processes can increase the legitimacy of the final decision, according to Duram and Brown (1999). Legitimacy examines decision-making sovereignty and whether procedural weaknesses or breaches exists that lead to an invalid process or results. Legitimate processes are defined by Carr et al. (2012) as processes that include consensual decision making and shared power.

A transparent process that provides clarity about the procedure, deliverables, tasks, and responsibilities as well as the principles and rules is seen to establish legitimacy and increase learning opportunities (Tippett et al. 2005, van de Kerkhof and Wieczorek 2005). Mostert et al. (2007) found that clarity regarding the definition of roles as well as the means, timing, and purpose of participation are the most important factors influencing social learning. Schusler et al. (2003) stress the importance of following a "democratic structure", which refers to participants' ability to decide on an agenda and procedures. This structure could provide unplanned opportunities for collaboration and thus push the limits of predetermined agendas set by government authorities. Muro and Jeffrey's (2012) and Schusler et al.'s (2003) research indicates that participants' greater process control enhances social learning. The perception of the problem may differ from participant to participant, which calls for joint definition of the problem and consideration of all perspectives to create a learning atmosphere (Mostert et al. 2007, Kumler and Lemos 2008). Ultimately, a group agreement of this kind may indicate shared understanding (Koontz 2014).

\section{Intermediate process outcomes}

Trust

Rowe and Frewer (2000:24) argue that for successful participation in decision making, it is necessary to "enhance trust in regulators and transparency in regulatory systems." However, empirical studies investigating the issue of trust in participation indicate that the relationship between trust and successful participation is more complex (Beierle and Konisky 2000, Yandle et al. 2011).

Many scholars emphasize the importance of trust in learning processes. Leach et al. (2014) found that the level of social learning is correlated with trust among participants. This correlation can 
be explained by the enhancement of a smooth process and the exchange of knowledge due to a trustworthy environment. More precisely, scholars argue that trust helps participants to open up and share insights and information (Reed 2008) or to deal with uncertainties and elements of social learning such as change (Pahl-Wostl et al. 2007). Koontz (2014) argues that the process of trust building indicates a perception of other participants as being true to their word or commitments, meaning that people are also willing to expose weaknesses to others. De Vries et al.'s (2017) study indicates that trust between participants depends on interaction patterns that are characterized by listening and showing concern for each other's position and perspective. They conclude that respect and appreciation are more important drivers of trust than are long dialogic processes. Webler et al. (1995) point out that trust in facilitators is especially important and, thus, a trust-building process must take place to establish such a relationship. This idea implies that a longer process is needed to build trust. In summary, trust seems to be both influenced by other factors and influences other factors (in addition to social learning) such as procedural fairness.

\section{Network building}

Network building refers to processes that either establish new or strengthen existing relationships between participants, creating benefits of gaining resources, insights, and cooperation on tasks (Koontz 2014).

Existing networks affect social learning because access to sources and integration of information and knowledge depend on the composition of the members involved (Gerlak and Heikkila 2011). Thus, network building can expand access to a wider variety of information and knowledge sources that influence social learning (Crona and Parker 2012). Network building is assumed to foster the integration of multiple interests and thus enhance social learning, but this requires further investigation (Benson et al. 2016).

\section{Conflict resolution}

Resolving or reducing conflict is often a seen as a goal of participation (Beierle and Cayford 2002). Following Cuppen's (2018) definition, conflict is an attempt by people to articulate and advocate their concerns and interests that are perceived as being insufficiently represented and considered by decision makers. Conflict is a process closely tied to the participation process and can encourage participation, enable learning processes, and avoid unproductive outcomes (Cuppen 2018). Consensus is often understood as having overcome a conflict or indicates that participants have reached an agreeable decision, which does not necessarily result in a high-quality decision (Carr et al. 2012).

The degree of conflict or tension between parties within the process is assumed to affect social learning (Muro and Jeffrey 2012). Beers et al. (2016) highlight that disagreement is important for social learning because constructive conflict, rather than participants merely complementing each other's information and ideas, would enhance shared mental models. These conflicts and tensions should not be avoided but mediated by skilled facilitation (Brown et al. 2005). In contrast, Knoepfel and Kissling-Näf (1998) argue that consensus on problem recognition, the need for action, and selection of instruments and processes during the implementation phase needs to form among participants to enable negotiation and ultimately to reach a valid decision. There is a lack of research providing a more in-depth look at the causes of conflict, such as different values, vested interests (Siebenhüner et al. 2016), and power relationships (Egunyu and Reed 2015, Gerlak et al. 2018).

\section{DISCUSSION}

Previous studies have found that social learning varies in its intensity (Muro and Jeffrey 2012) and that a participatory process can enhance knowledge of a specific environmental problem and about the interests and concerns of various stakeholders (Webler et al. 1995, Schusler et al. 2003, Muro and Jeffrey 2012). Knoepfel and Kissling-Näf (1998) reason that it is essential for collective learning processes that knowledge is developed on a cooperative basis and made accessible to various actors. They suggest that the dissemination of knowledge depends on individual cognitive change, the compatibility of information with existing beliefs, the quality of information, and political pressure for change. According to Brown et al. (2005) and Tippett et al. (2005), the participatory format should form spaces for reflection and open exchange, which are considered key elements for the successful integration of different knowledge types, norms, and values. Such a learning environment is supposedly characterized by the establishment of new perspectives for the actors involved, helping them to become aware of their knowledge and conduct from a distance (Westberg and Polk 2016).

However, the metareviews of Gerlak et al. (2018) and Siebenhüner et al. (2016) found that the causes of social learning are insufficiently studied. My narrative literature analyzed empirical findings to detect factors that influence social learning. In Table 1, I summarize these findings and show how the factors influencing social learning are interconnected.

My narrative literature review demonstrates how empirical findings suggest different desirable values for single factors. Furthermore, the desirable target values of factors might be conflicting. For instance, inclusive participation aiming to involve everyone might contradict in-depth, face-to-face dialogue, which is only possible with a limited number of participants. Thus, in practice, there is a need to balance different factors. The review not only showed that social learning processes within the scope of participatory environmental governance are multidimensional and dynamic (Muro and Jeffrey 2012), but that the factors influencing social learning are interconnected and interdependent. For instance, a trustworthy relationship between facilitator and participants is necessary to foster productive knowledge exchange. However, trust needs to evolve and may depend on other factors such as the duration of the participation process. Therefore, in line with several other scholars (Webler 1995, Beierle and Cayford 2002, Carr et al. 2012, Biddle and Koontz 2014), I conclude that to understand social learning processes fully, the interconnections between participation process characteristics, intermediate outcomes, normative process factors, and elements of social learning such as acquisition of information and cognitive change need to be investigated explicitly.

Fig. 1 further illustrates the interconnections and dependencies of factors influencing social learning. The factors categorized as intermediate outcomes and normative process factors represent a hybrid form of dependent and independent variables because they are influenced by participation process characteristics and 
Table 1. Factors influencing social learning.

\begin{tabular}{|c|c|c|c|}
\hline Generic category & Factor & Value & Affected by \\
\hline \multirow[t]{6}{*}{$\begin{array}{l}\text { Participation process } \\
\text { characteristics }\end{array}$} & Participation format & $\begin{array}{l}\text { Dialogic, face to face, multiple times, } \\
\text { equal opportunities }\end{array}$ & Context \\
\hline & Access to information & $\begin{array}{l}\text { Scientific quality, easy to access and } \\
\text { understand }\end{array}$ & \\
\hline & Facilitation & $\begin{array}{l}\text { Independent, mediator, manage power } \\
\text { imbalances, limit barriers to participation }\end{array}$ & $\begin{array}{l}\text { Participation format, context, participant } \\
\text { characteristics }\end{array}$ \\
\hline & Diversity of participants & $\begin{array}{l}\text { Balance between homogeneity and } \\
\text { heterogeneity }\end{array}$ & $\begin{array}{l}\text { Facilitation, conflict within the } \\
\text { participation process }\end{array}$ \\
\hline & Participants' characteristics & $\begin{array}{l}\text { Knowledge, perception of one's own } \\
\text { capacity }\end{array}$ & \\
\hline & Context & Urgent topic, institutions, uncertainty & \\
\hline \multirow[t]{3}{*}{ Normative process factors } & Procedural fairness & Equal participation, fair rules & Participation format, facilitation, trust \\
\hline & Legitimacy & Process control, transparency & $\begin{array}{l}\text { Facilitation, diversity of participants, } \\
\text { procedural fairness }\end{array}$ \\
\hline & $\begin{array}{l}\text { Effectiveness, efficiency, } \\
\text { satisfaction }\end{array}$ & $\begin{array}{l}\text { Impact, output worth the effort, } \\
\text { perception of individual effect on process }\end{array}$ & \\
\hline \multirow{3}{*}{$\begin{array}{l}\text { Intermediate process } \\
\text { outcomes }\end{array}$} & Trust & Being true to word, reliable & Participation format, facilitation, context \\
\hline & Network building & Establish or strengthen social contacts & $\begin{array}{l}\text { Existing social contacts, participants' } \\
\text { characteristics }\end{array}$ \\
\hline & Conflict resolution & $\begin{array}{l}\text { A moderate amount of disagreement, } \\
\text { balanced power relationships }\end{array}$ & $\begin{array}{l}\text { Context, trust, participants' } \\
\text { characteristics, facilitation }\end{array}$ \\
\hline
\end{tabular}

also explain social learning. The directions of influence and interdependencies (Fig. 1) represent assumptions, to some extent. Whether these connections are causalities or correlations needs to be tested. My review shows that certain relations and effects have not been sufficiently analyzed, such as the influence of gender or age on social learning. These interconnections between causes and effects are addressed by the reviewed literature, but a systematic analysis is lacking. The concept is a product of existing research but with research gaps that need to be further investigated.

Fig. 1. Interconnections and directions of influence among participation process characteristics, normative process criteria, intermediate outcomes, and social learning.

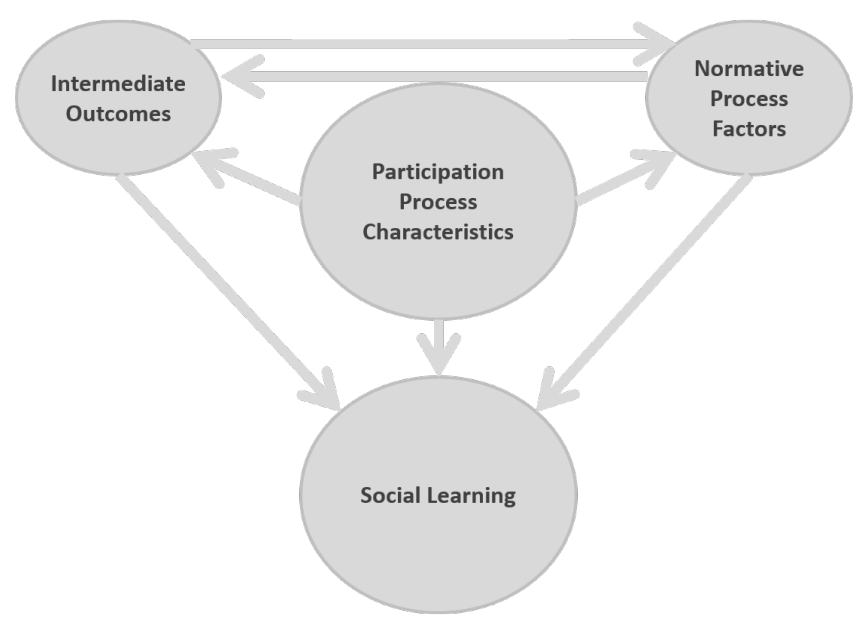

The literature evaluating participation processes is often concerned with normative goals such as effectiveness and efficiency. However, these goals were rarely considered in the literature on social learning. These differences might be explained by the different research foci of the two fields. Nevertheless, the comparison of the two research strands made it possible to identify additional potential factors such as effectiveness, efficiency, and satisfaction, which otherwise would have been overlooked. Findings from other research fields (Ringberg and Reihlen 2008, Glowacki and Molleman 2017) imply that the inclusion of individuals' characteristics and preexisting attitudes could further improve assessments of social learning in participatory environmental governance.

The majority of literature reviewed comprised case studies from Western democratic countries (Appendix 1). Thus, the findings discussed here may not be applicable in other political and cultural contexts. Contextual factors such as existing institutions, rules, and social norms influence social learning, but these factors have not been analyzed fully. Factors such as access to information, legitimacy, and procedural fairness describe democratic decisionmaking procedures. It is assumed that participatory spaces that provide options of codecision and open negotiations do not exist in nondemocratic regimes. Therefore, it can be questioned how social learning can take place in autocratic regimes that deny access to information. Social learning is assumed to lead to social change, i.e., change in institutions, norms, and behaviors, which is not desired by autocratic regimes. These factors are closely connected to the question of which governance formats promote sustainable development (Adger and Jordan 2009, Atkinson et al. 2011).

The reviewed literature revealed some important research gaps. Although cognitive change is considered to be the main element of a social learning process, this aspect has hardly been studied. 
Most of the reviewed literature reported on acquiring new information. To account for the variety of factors influencing outcomes, an evaluation of participation should not only measure whether goals were achieved but investigate the specific factors determining each participation process (Koebele 2015). Most literature focused on the process and hardly discussed aspects taking place after the participation process had ended. However, Jami and Walsh (2016) argue that the outcomes only become apparent beyond the immediate end of the participation process, especially when it comes to learning processes that lead to community building and improved trust in decision making. This perspective calls for research designs that collect data after the participation process has ended. Further research in this field should test the deduced factors using a noncase-study design and investigate participation processes characterized by less intensive communication and dialogue to provide broader methodical and contextual variety to the body of empirical evidence. Each research technique and method measuring social learning has limitations, so the research design must be chosen based on the specific research interest and may also depend on the resources (money, time) available.

\section{CONCLUSIONS}

I report on the current and ongoing debate concerning how social learning is stimulated by participatory environmental governance. I applied a narrative review and offered an in-depth qualitative description of factors that influence social learning by comparing empirical results. The findings provide a conceptual and empirical understanding of how participatory environmental governance fosters social learning and contributes to a transformation toward sustainable development.

The literature review supports previous findings that research is focused on process-related factors such as facilitation and participation format and rarely on intermediate outcomes such as trust (Biddle and Koontz 2014). The most commonly applied methods are ex-post evaluations looking at case studies, case surveys, or empirical studies focusing on a specific region mainly in Western democracies. Many studies focus on water governance, which indicates a long tradition of participatory governance in water governance, especially in the USA (Sabatier et al. 2005). Participation within the context of energy-related issues appears to be an emerging research field. The concept of social learning has been an aspect of scientific investigation for some time. Although cognitive change is an essential element of social learning and is discussed as the main driver of social change processes, empirical evidence of cognitive change was detected less often than other elements of social learning such as acquisition of information. Furthermore, Muro and Jeffrey (2012) point out that acquiring knowledge does not necessarily lead to a change in perspective. This result indicates the need for more empirical assessments of social learning within the scope of participatory environmental governance.

Evaluation studies are not excluded from bias because the values and attitudes of the authors are reflected in the evaluation criteria (Conley and Moote 2003), which greatly influence the results (Carr et al. 2012). I first identified the factors influencing social learning by evaluating theory-based literature in the field of participation research, and then I discussed each factor with empirical findings from literature assessing social learning in participatory environmental governance. Reviewing papers from two strands of research and comparing theoretical assumptions with empirical evidence has not only helped to deduce factors that are less biased, but also to provide an in-depth understanding of the interconnections and interdependencies among the factors influencing social learning. However, the identified research gaps need to be addressed to understand social learning fully. Because of the amount of literature reviewed (72 publications) and the significant overlap of factors and issues cited in the literature, it can be assumed that this review provides a holistic assessment of the empirical evidence.

Although some participation research studies as well as studies assessing social learning have highlighted the importance of differentiating between causes (processes) and effects (outcomes), most studies did not clearly define independent and dependent variables. The findings suggest that there might not be a direct causal relationship between the design of participation processes and social learning, but perceptions of the process as fair or legitimate, and intermediate outcomes such as trust, have a strong influence on social learning. For instance, the intensity and duration of the participation process influences the intermediate outcome of trust, which in turn enhances social learning. The further and in-depth investigation of these interconnections might help in making informed choices about how to facilitate participation processes. Some process characteristics conflict in the sense that an inclusive process might not result in intensive face-to-face dialogue. Therefore, future investigation of how factors and their interactions affect outcomes can help to provide recommendations for facilitating participation processes in practice.

Responses to this article can be read online at: http://www.ecologyandsociety.org/issues/responses. php/10599

\section{Acknowledgments:}

I am grateful to Doris Fuchs, Diana Schumann, Carolin Märker, and Wolfgang Fischer for their valuable feedback, which helped to sharpen the paper. The comments of two anonymous reviewers helped to improve the structure and logic of the arguments presented.

\section{LITERATURE CITED}

Adger, W. N., and A. Jordan, editors. 2009. Governing sustainability. Cambridge University Press, Cambridge, UK. http://dx.doi.org/10.1017/CBO9780511807756

Armitage, D., M. Marschke, and R. Plummer. 2008. Adaptive comanagement and the paradox of learning. Global Environmental Change 18(1):86-98. http://dx.doi.org/10.1016/j.gloenvcha.2007.07.002

Atkinson, R., G. Terizakis, and K. Zimmermann, editors. 2011. Sustainability in European environmental policy: challenges of governance and knowledge. Routledge, London, UK. http://dx. doi.org/10.4324/9780203841716

Baird, J., R. Plummer, C. Haug, and D. Huitema. 2014. Learning effects of interactive decision-making processes for climate 
change adaptation. Global Environmental Change 27:51-63. http:// dx.doi.org/10.1016/j.gloenvcha.2014.04.019

Baumeister, R. F., and M. R. Leary. 1997. Writing narrative literature reviews. Review of General Psychology 1(3):311-320. http://dx.doi.org/10.1037/1089-2680.1.3.311

Beers, P. J., B. van Mierlo, and A.-C. Hoes. 2016. Toward an integrative perspective on social learning in system innovation initiatives. Ecology and Society 21(1):33. http://dx.doi. org/10.5751/ES-08148-210133

Beierle, T. C. 2002. The quality of stakeholder-based decisions. Risk Analysis 22(4):739-749. http://dx.doi.org/10.1111/0272-4332.00065

Beierle, T. C., and J. Cayford. 2002. Democracy in practice: public participation in environmental decisions. Resources for the Future, Washington, D.C., USA.

Beierle, T. C., and D. M. Konisky. 2000. Values, conflict, and trust in participatory environmental planning. Journal of Policy Analysis and Management 19(4):587-602. http://dx.doi. org/10.1002/1520-6688(200023)19:4<587::AID-PAM4>3.0.CO;2Q

Benson, D., I. Lorenzoni, and H. Cook. 2016. Evaluating social learning in England flood risk management: An 'individualcommunity interaction' perspective. Environmental Science and Policy 55(2):326-334. http://dx.doi.org/10.1016/j.envsci.2015.05.013

Berman, T. 2017. Public participation as a tool for integrating local knowledge into spatial planning: planning, participation, and knowledge. Springer, Cham, Switzerland. http://dx.doi. org/10.1007/978-3-319-48063-3

Biddle, J. C., and T. M. Koontz. 2014. Goal specificity: a proxy measure for improvements in environmental outcomes in collaborative governance. Journal of Environmental Management 145:268-276. http://dx.doi.org/10.1016/j.jenvman.2014.06.029

Brown, V. A., M. Keen, and R. Dyball. 2005. Lessons from the past, learning for the future. Pages 247-264 in M. Keen, V. A. Brown, and R. Dyball, editors. Social learning in environmental management: towards a sustainable future. Earthscan, London, UK.

Burgess, J., and J. Clark. 2009. Practitioner evaluations of participatory processes in environmental decision making. Pages 159-190 in W. N. Adger and A. Jordan, editors. Governing sustainability. Cambridge University Press, Cambridge, UK. http://dx.doi.org/10.1017/CBO9780511807756.010

Carr, G., G. Blöschl, and D. P. Loucks. 2012. Evaluating participation in water resource management: a review. Water Resources Research 48(11):W11401. http://dx.doi. org/10.1029/2011WR011662

Caspersen, J., J.-C. Smeby, and P. O. Aamodt. 2017. Measuring learning outcomes. European Journal of Education 52(1):20-30. http://dx.doi.org/10.1111/ejed.12205

Coenen, F. H. J. M. 2009. Introduction. Pages 1-20 in F. H. J. M. Coenen, editor. Public participation and better environmental decisions. Springer, Cham, Switzerland.

Coenen, F. H. J. M., D. Huitema, and L. J. O’Toole. 1998. Participation and envrionmental decsion quality: an assessment.
Pages 307-326 in F. H. J. M. Coenen, D. Huitema, and L. J. O'Toole, editors. Participation and the quality of envrionmental decision making. Kluwer, Dodrecht, The Netherlands.

Conley, A., and M. A. Moote. 2003. Evaluating collaborative natural resource management. Society and Natural Resources 16 (5):371-386. https://doi.org/10.1080/08941920309181

Crona, B. I., and J. N. Parker. 2012. Learning in support of governance: theories, methods, and a framework to assess how bridging organizations contribute to adaptive resource governance. Ecology and Society 17(1):32. http://dx.doi. org/10.5751/ES-04534-170132

Cundill, G. 2010. Monitoring social learning processes in adaptive comanagement: three case studies from South Africa. Ecology and Society 15(3):28. http://dx.doi.org/10.5751/ES-03467-150328

Cuppen, E. 2018. The value of social conflicts. Critiquing invited participation in energy projects. Energy Research and Social Science 38:28-32. https://doi.org/10.1016/j.erss.2018.01.016

de Vries, J. R., S. van Bommel, C. Blackmore, and Y. Asano. 2017. Where there is no history: how to create trust and connection in learning for transformation in water governance. Water 9(2):130. http://dx.doi.org/10.3390/w9020130

Duram, L. A., and K. G. Brown. 1999. Assessing public participation in U.S. watershed planning initiatives. Society and Natural Resources 12(5):455-467. https://doi.org/10.1080/089419299279533

Edelenbos, J., A. van Buuren, and N. van Schie. 2011. Coproducing knowledge: joint knowledge production between experts, bureaucrats and stakeholders in Dutch water management projects. Environmental Science and Policy 14 (6):675-684. http://dx.doi.org/10.1016/j.envsci.2011.04.004

Egunyu, F., and M. G. Reed. 2015. Social learning by whom? Assessing gendered opportunities for participation and social learning in collaborative forest governance. Ecology and Society 20(4):44. http://dx.doi.org/10.5751/ES-08126-200444

Elbakidze, M., L. Dawson, K. Andersson, R. Axelsson, P. Angelstam, I. Stjernquist, S. Teitelbaum, P. Schlyter, and C. Thellbro. 2015. Is spatial planning a collaborative learning process? A case study from a rural-urban gradient in Sweden. Land Use Policy 48:270-285. http://dx.doi.org/10.1016/j. landusepol.2015.05.001

Ernst, A., A. Fischer-Hotzel, and D. Schumann. 2017. Transforming knowledge for sustainability: insights from an inclusive science-practice dialogue on low-carbon society in Germany. Energy Research and Social Science 29:23-35. http://dx. doi.org/10.1016/j.erss.2017.04.006

Fiorino, D. J. 1990. Citizen participation and environmental risk: a survey of institutional mechanisms. Science, Technology, and Human Values 15(2):226-243. http://dx.doi.org/10.1177/0162243$\underline{99001500204}$

Garmendia, E., and S. Stagl. 2010. Public participation for sustainability and social learning: concepts and lessons from three case studies in Europe. Ecological Economics 69(8):1712-1722. http://dx.doi.org/10.1016/j.ecolecon.2010.03.027 
Gerlak, A. K., and T. Heikkila. 2011. Building a theory of learning in collaboratives: evidence from the Everglades restoration program. Journal of Public Administration Research and Theory 21(4):619-644. http://dx.doi.org/10.1093/jopart/ $\underline{\text { muq089 }}$

Gerlak, A. K., T. Heikkila, S. L. Smolinski, D. Huitema, and D. Armitage. 2018. Learning our way out of environmental policy problems: a review of the scholarship. Policy Sciences 51 (3):335-371. http://dx.doi.org/10.1007/s11077-017-9278-0

Giebels, D., A. van Buuren, and J. Edelenbos. 2016. Knowledge governance for ecosystem-based management: understanding its context-dependency. Environmental Science and Policy 55 (3):424-435. http://dx.doi.org/10.1016/j.envsci.2015.08.019

Glowacki, L., and L. Molleman. 2017. Subsistence styles shape human social learning strategies. Nature Human Behaviour 1:0098. http://dx.doi.org/10.1038/s41562-017-0098

Green, B. N., C. D. Johnson, and A. Adams. 2006. Writing narrative literature reviews for peer-reviewed journals: secrets of the trade. Journal of Chiropractic Medicine 5(3):101-117. http:// dx.doi.org/10.1016/S0899-3467(07)60142-6

Heikkila, T., and A. K. Gerlak. 2013. Building a conceptual approach to collective learning: lessons for public policy scholars. Policy Studies Journal 41(3):484-512. http://dx.doi.org/10.1111/ psj.12026

Huitema, D., C. Cornelisse, and B. Ottow. 2010. Is the jury still out? Toward greater insight in policy learning in participatory decision processes - the case of Dutch citizens' juries on water management in the Rhine basin. Ecology and Society 15(1):16. [online] URL: http://www.ecologyandsociety.org/vol15/iss1/ $\underline{\operatorname{art} 16 /}$

Jami, A. A., and P. R. Walsh. 2016. Wind power deployment: the role of public participation in the decision-making process in Ontario, Canada. Sustainability 8(8):713. http://dx.doi. org/10.3390/su8080713

Jennings, E. T. Jr., and J. L. Hall. 2012. Evidence-based practice and the use of information in state agency decision making. Journal of Public Administration Research and Theory 22 (2):245-266. http://dx.doi.org/10.1093/jopart/mur040

Knoepfel, P., and I. Kissling-Näf. 1998. Social learning in policy networks. Policy and Politics 26(3):343-367. http://dx.doi. org/10.1332/030557398782213638

Koebele, E. A. 2015. Assessing outputs, outcomes, and barriers in collaborative water governance: a case study. Journal of Contemporary Water Research and Education 155(1):63-72. http:// dx.doi.org/10.1111/j.1936-704X.2015.03196.x

Koontz, T. M. 2014. Social learning in collaborative watershed planning: the importance of process control and efficacy. Journal of Environmental Planning and Management 57(10):1572-1593. http://dx.doi.org/10.1080/09640568.2013.820658

Koontz, T. M., and E. M. Johnson. 2004. One size does not fit all: matching breadth of stakeholder participation to watershed group accomplishments. Policy Sciences 37(2):185-204. http://dx. doi.org/10.1023/B:OLIC.0000048532.94150.07
Kumler, L. M., and M. C. Lemos. 2008. Managing waters of the Paraíba do Sul River basin, Brazil: a case study in institutional change and social learning. Ecology and Society 13(2):22. [online] URL: http://www.ecologyandsociety.org/vol13/iss2/art22/

Leach, W. D., and N. W. Pelkey. 2001. Making watershed partnerships work: a review of the empirical literature. Journal of Water Resources Planning and Management 127(6):378-385. http://dx.doi.org/10.1061/(ASCE)0733-9496(2001)127:6(378)

Leach, W. D., N. W. Pelkey, and P. A. Sabatier. 2002. Stakeholder partnerships as collaborative policymaking: evaluation criteria applied to watershed management in California and Washington. Journal of Policy Analysis and Management 21(4):645-670. http:// dx.doi.org/10.1002/pam.10079

Leach, W. D., and P. A. Sabatier. 2005. To trust an adversary: integrating rational and psychological models of collaborative policymaking. American Political Science Review 99(4):491-503. http://dx.doi.org/10.1017/S000305540505183X

Leach, W. D., C. M. Weible, S. R. Vince, S. N. Siddiki, and J. C. Calanni. 2014. Fostering learning through collaboration: knowledge acquisition and belief change in marine aquaculture partnerships. Journal of Public Administration Research and Theory 24(3):591-622. http://dx.doi.org/10.1093/jopart/mut011

Mostert, E., C. Pahl-Wostl, Y. Rees, B. Searle, D. Tàbara, and J. Tippett. 2007. Social learning in European river-basin management: barriers and fostering mechanisms from 10 river basins. Ecology and Society 12(1):19. [online] URL: http://www. ecologyandsociety.org/vol12/iss1/art19/

Muro, M. 2008. The role of social learning in participatory planning and management of water resources. Dissertation. Cranfield University, Cranfield, UK. [online] URL: http://hdl.handle. net/1826/3513

Muro, M., and P. Jeffrey. 2008. A critical review of the theory and application of social learning in participatory natural resource management processes. Journal of Environmental Planning and Management 51(3):325-344. http://dx.doi.org/10.1080/09640560$\underline{801977190}$

Muro, M., and P. Jeffrey. 2012. Time to talk? How the structure of dialog processes shapes stakeholder learning in participatory water resources management. Ecology and Society 17(1):3. http:// dx.doi.org/10.5751/ES-04476-170103

Natarajan, L. 2017. Socio-spatial learning: a case study of community knowledge in participatory spatial planning. Progress in Planning 111:1-23. http://dx.doi.org/10.1016/j.progress.2015.06.002

Newig, J., E. Challies, N. W. Jager, E. Kochskaemper, and A. Adzersen. 2018. The environmental performance of participatory and collaborative governance: a framework of causal mechanisms. Policy Studies Journal 46(2):269-297. http://dx.doi. org/10.1111/psj.12209

O’Toole, L. J. Jr., and K. J. Meier. 2014. Public management, context, and performance: in quest of a more general theory. Journal of Public Administration Research and Theory 25 (1):237-256. http://dx.doi.org/10.1093/jopart/muu011

Pahl-Wostl, C., M. Craps, A. Dewulf, E. Mostert, D. Tabara, and T. Taillieu. 2007. Social learning and water resources 
management. Ecology and Society 12(2):5. http://dx.doi. org/10.5751/ES-02037-120205

Palm, J., and J. Thoresson. 2014. Strategies and implications for network participation in regional climate and energy planning. Journal of Environmental Policy and Planning 16(1):3-19. http:// dx.doi.org/10.1080/1523908X.2013.807212

Parés, M., Q. Brugué, J. Espluga, J. Miralles, and A. Ballester. 2015. The strengths and weaknesses of deliberation on river basin management planning: analysing the water framework directive implementation in Catalonia (Spain). Environmental Policy and Governance 25(2):97-110. http://dx.doi.org/10.1002/eet.1662

Peterson, N. D., K. Broad, B. Orlove, C. Roncoli, R. Taddei, and M.-A. Velez. 2010. Participatory processes and climate forecast use: socio-cultural context, discussion, and consensus. Climate and Development 2(1):14-29. http://dx.doi.org/10.3763/cdev.2010.0033

Petts, J. 2006. Managing public engagement to optimize learning: reflections from urban river restoration. Human Ecology Review 13(2):172-181. [online] URL: http://www.apjh.humanecologyreview. org/pastissues/her132/petts.pdf

Podestá, G. P., C. E. Natenzon, C. Hidalgo, and F. R. Toranzo. 2013. Interdisciplinary production of knowledge with participation of stakeholders: a case study of a collaborative project on climate variability, human decisions and agricultural ecosystems in the Argentine Pampas. Environmental Science and Policy 26:40-48. http://dx.doi.org/10.1016/j.envsci.2012.07.008

Pohl, C., S. Rist, A. Zimmermann, P. Fry, G. S. Gurung, F. Schneider, C. I. Speranza, B. Kiteme, S. Boillat, E. Serrano, G. Hirsch Hadorn, and U. Wiesmann. 2010. Researchers' roles in knowledge co-production: experience from sustainability research in Kenya, Switzerland, Bolivia and Nepal. Science and Public Policy 37(4):267-281. http://dx.doi.org/10.3152/030234210X496628

Reed, M. S. 2008. Stakeholder participation for environmental management: a literature review. Biological Conservation 141 (10):2417-2431. http://dx.doi.org/10.1016/j.biocon.2008.07.014

Reed, M. S., A. C. Evely, G. Cundill, I. Fazey, J. Glass, A. Laing, J. Newig, B. Parrish, C. Prell, C. Raymond, and L. C. Stringer. 2010. What is social learning? Ecology and Society 15(4):r1. [online] URL: http://www.ecologyandsociety.org/vol15/iss4/ $\underline{\text { resp1/ }}$

Renn, O. 2005. Partizipation - ein schillernder Begriff: reaktion auf drei Beiträge zum thema "Partizipation" in GAIA 14/1 (2005) und GAIA 14/3 (2005). GAIA - Ecological Perspectives for Science and Society 14(3):227-228. https://doi.org/10.14512/gaia.14.3.8

Renn, O. 2006. Participatory processes for designing environmental policies. Land Use Policy 23(1):34-43. http://dx. doi.org/10.1016/j.landusepol.2004.08.005

Ringberg, T., and M. Reihlen. 2008. Towards a socio-cognitive approach to knowledge transfer. Journal of Management Studies 45(5):912-935. http://dx.doi.org/10.1111/j.1467-6486.2007.00757. $\underline{\mathrm{x}}$

Roberts, P. D., G. B. Stewart, and A. S. Pullin. 2006. Are review articles a reliable source of evidence to support conservation and environmental management? A comparison with medicine. Biological Conservation 132(4):409-423. http://dx.doi.org/10.1016/ j.biocon.2006.04.034
Roldán, A. M. 2017. Political regime and learning outcomes of stakeholder participation: cross-national study of 81 Biosphere Reserves. Sustainability 9(4):553. https://doi.org/10.3390/su9040553

Rowe, G., and L. J. Frewer. 2000. Public participation methods: a framework for evaluation. Science, Technology, and Human Values 25(1):3-29. http://dx.doi.org/10.1177/016224390002500101

Sabatier, P. A., C. Weible, and J. Ficker. 2005. Eras of water management in the United States: implications for collaborative watershed approaches. Pages 23-52 in P. A. Sabatier, W. Focht, M. Lubell, Z. Trachtenberg, A. Vedlitz, and M. Matlock, editors. Swimming upstream: collaborative approaches to watershed management. MIT Press, Cambridge, Massachusetts, USA.

Schroeter, R., O. Scheel, O. Renn, and P.-J. Schweizer. 2016. Testing the value of public participation in Germany: theory, operationalization and a case study on the evaluation of participation. Energy Research and Social Science 13:116-125. http://dx.doi.org/10.1016/j.erss.2015.12.013

Schusler, T. M., D. J. Decker, and M. J. Pfeffer. 2003. Social learning for collaborative natural resource management. Society and Natural Resources 16(4):309-326. http://dx.doi. org/10.1080/08941920390178874

Siebenhüner, B., R. Rodela, and F. Ecker. 2016. Social learning research in ecological economics: a survey. Environmental Science and Policy 55(1):116-126. http://dx.doi.org/10.1016/j.envsci.2015.09.010

Squires, H., and O. Renn. 2011. Can participatory modelling support social learning in marine fisheries? Reflections from the Invest in Fish South West project. Environmental Policy and Governance 21(6):403-416. http://dx.doi.org/10.1002/eet.588

Tippett, J., B. Searle, C. Pahl-Wostl, and Y. Rees. 2005. Social learning in public participation in river basin management - early findings from HarmoniCOP European case studies. Environmental Science and Policy 8(3):287-299. http://dx.doi.org/10.1016/j. envsci.2005.03.003

van de Kerkhof, M., and A. Wieczorek. 2005. Learning and stakeholder participation in transition processes towards sustainability: methodological considerations. Technological Forecasting and Social Change 72(6):733-747. http://dx.doi. org/10.1016/j.techfore.2004.10.002

van der Wal, M., J. De Kraker, A. Offermans, C. Kroeze, P. A. Kirschner, and M. van Ittersum. 2014. Measuring social learning in participatory approaches to natural resource management. Environmental Policy and Governance 24(1):1-15. http://dx.doi. org/10.1002/eet.1627

Verba, S., K. L. Schlozman, and H. E. Brady. 1995. Voice and equality: civic voluntarism in American politics. Harvard University Press, Cambridge, Massachusetts, USA.

von Korff, Y., K. A. Daniell, S. Moellenkamp, P. Bots, and R. M. Bijlsma. 2012. Implementing participatory water management: recent advances in theory, practice, and evaluation. Ecology and Society 17(1):30. http://dx.doi.org/10.5751/ES-04733-170130

Waylen, K. A., K. L. Blackstock, K. B. Marshall, and J. Dunglinson. 2015. Participation-prescription tension in natural resource management: the case of diffuse pollution in Scottish water management. Environmental Policy and Governance 25 (2):111-124. http://dx.doi.org/10.1002/eet.1666 
Webler, T. 1995. "Right" discourse in citizen participation: an evaluative yardstick. Pages 35-86 in O. Renn, T. Webler, and P. Wiedemann, editors. Fairness and competence in citizen participation: evaluating models for environmental discourse. Kluwer, Dordrecht, The Netherlands.

Webler, T., H. Kastenholz, and O. Renn. 1995. Public participation in impact assessment: a social learning perspective. Environmental Impact Assessment Review 15(5):443-463. http:// dx.doi.org/10.1016/0195-9255(95)00043-E

Webler, T., and S. Tuler. 2000. Fairness and competence in citizen participation: theoretical reflections from a case study. Administration and Society 32(5):566-595. http://dx.doi. org/10.1177/00953990022019588

Westberg, L., and M. Polk. 2016. The role of learning in transdisciplinary research: moving from a normative concept to an analytical tool through a practice-based approach. Sustainability Science 11(3):385-397. http://dx.doi.org/10.1007/ s11625-016-0358-4

Wiek, A. 2007. Challenges of transdisciplinary research as interactive knowledge generation - experiences from transdisciplinary case study research. Gaia-Ecological Perspectives for Science and Society 16(1):52-57. http://dx.doi.org/10.14512/gaia.16.1.14

Wilner, K. B., M. Wiber, A. Charles, J. Kearney, M. Landry, L. Wilson, and on behalf of the Coastal CURA Team. 2012. Transformative learning for better resource management: the role of critical reflection. Journal of Environmental Planning and Management 55(10):1331-1347. http://dx.doi.org/10.1080/09640$\underline{568.2011 .646679}$

Yandle, T., N. Hajj, and R. Raciborski. 2011. The goldilocks solution: exploring the relationship between trust and participation in resource management within the New Zealand commercial rock lobster fishery. Policy Studies Journal 39 (4):631-658. http://dx.doi.org/10.1111/j.1541-0072.2011.00425.x

Young, O. R. 1997. Rigths, rules, and resources in world affairs. Pages 1-24 in O. R. Young, editor. Global governance: drawing insights from the environmental experience. MIT Press, Cambridge, Massachusetts, USA. 


\section{APPENDIX}

Table 1: Overview Reviewed Literature Evaluation of Participation in Chronical Orde

\begin{tabular}{|c|c|c|c|c|c|c|}
\hline No & Reference & Purpose of the study & Methods & Evaluation/Success Criteria & Conclusions & Limitations \\
\hline 1 & $\begin{array}{l}\text { Fiorino } \\
(1990)\end{array}$ & $\begin{array}{l}\text { Defining democratic } \\
\text { criteria for assessing } \\
\text { participatory mechanisms }\end{array}$ & Theory/ Review & $\begin{array}{l}\text { Ensure stronger democratic processes: Direct } \\
\text { participation of lay people; citizens to share in collective } \\
\text { decision making; face-to-face discussion over some period } \\
\text { of time; participation on some basis of equality with } \\
\text { administrators and technical specialists }\end{array}$ & $\begin{array}{l}\text { Instrumental and substantive criteria } \\
\text { are also important }\end{array}$ & $\begin{array}{l}\text { Normative } \\
\text { assessment }\end{array}$ \\
\hline 2 & $\begin{array}{l}\text { Webler } \\
\text { (1995) }\end{array}$ & $\begin{array}{l}\text { Deducing a procedural } \\
\text { normative model }\end{array}$ & Theory & $\begin{array}{l}\text { Fairness and competence; Habermas ideal speech } \\
\text { situation; institutional constrains: Multiway- } \\
\text { communication, consensual and non-hierarchical } \\
\text { participation, autonomy of the individual and trust, } \\
\text { reasonableness of the citizenry and critical self-reflection }\end{array}$ & $\begin{array}{l}\text { Every criterion must be treated with a } \\
\text { degree of interpretation and flexibility }\end{array}$ & $\begin{array}{l}\text { Theoretical } \\
\text { argumentat } \\
\text { ion: no } \\
\text { empirical } \\
\text { prove }\end{array}$ \\
\hline 3 & $\begin{array}{l}\text { Coenen et al. } \\
(1998)\end{array}$ & $\begin{array}{l}\text { Considering the } \\
\text { relationship between } \\
\text { participation and decision } \\
\text { quality }\end{array}$ & $\begin{array}{l}\text { Summary and } \\
\text { conclusion of edited } \\
\text { book }\end{array}$ & & $\begin{array}{l}\text { More work on conceptualising and } \\
\text { measuring decision quality, } \\
\text { importance of the complex mix of } \\
\text { mediating circumstances surrounding } \\
\text { participatory efforts }\end{array}$ & \\
\hline 4 & \begin{tabular}{|l|} 
Duram and \\
Brown (1999)
\end{tabular} & $\begin{array}{l}\text { This research identified } \\
\text { five key factors to consider } \\
\text { when assessing public } \\
\text { participation in watershed } \\
\text { planning }\end{array}$ & $\begin{array}{l}\text { Mail survey of } 126 \\
\text { federally funded } \\
\text { watershed planning } \\
\text { initiatives yielded } \\
\text { valid } \\
\text { responses from } 64 \\
\text { watershed contacts, } \\
\text { USA }\end{array}$ & $\begin{array}{l}\text { Approaches to management; Planning stages that could } \\
\text { include participation; Methods to solicit participation; } \\
\text { Level of participation; Potential positive impacts of } \\
\text { participation on watershed }\end{array}$ & $\begin{array}{l}\text { Participatory can achieve local } \\
\text { resource goals. "Watershed planning } \\
\text { has brought about an awareness of } \\
\text { concerns that other people may not } \\
\text { have thought about or recognized as a } \\
\text { problem. Participatory w. } \\
\text { management tends to stimulate } \\
\text { interagency coordination and local } \\
\text { stakeholder involvement. This can lead } \\
\text { to the formulation of realistic plans } \\
\text { that address complex environmental } \\
\text { concerns. }\end{array}$ & $\begin{array}{l}\text { Only USA } \\
\text { and water }\end{array}$ \\
\hline 5 & $\begin{array}{l}\text { Beierle and } \\
\text { Konisky } \\
(2000)\end{array}$ & $\begin{array}{l}\text { Evaluation of case studies, } \\
\text { whether case studies } \\
\text { support optimism }\end{array}$ & $\begin{array}{l}\text { Case survey about } 29 \\
\text { case studies }\end{array}$ & $\begin{array}{l}\text { Context: Atmosphere conductive to agreement, attitude } \\
\text { toward lead agency, confidence in process, problems to } \\
\text { be addressed, scientific understanding, shared } \\
\text { jurisdiction, geographic complexity } \\
\text { Process: Scope of tasks, Deliberative process, } \\
\text { communication with lead agency, freedom of participants, } \\
\text { Bottom up vs. top down, commitment of lead agency, } \\
\text { perceived impact on decision making, leadership }\end{array}$ & $\begin{array}{l}\text { Four attributes related to one or more } \\
\text { of the three goals: quality of the } \\
\text { deliberative process; quality of } \\
\text { communication with government, } \\
\text { commitment of the lead agency, } \\
\text { degree to which jurisdiction over the } \\
\text { process was shared }\end{array}$ & $\begin{array}{l}\text { Not enough } \\
\text { information } \\
\text { on every } \\
\text { case, } \\
\text { limited } \\
\text { evidence }\end{array}$ \\
\hline 6 & Rowe and & Discusses a potential & Theory & Acceptance criteria: representativeness; independence; & A variety of contextual and & Theoretical \\
\hline
\end{tabular}




\begin{tabular}{|c|c|c|c|c|c|c|}
\hline No & Reference & Purpose of the study & Methods & Evaluation/Success Criteria & Conclusions & Limitations \\
\hline & $\begin{array}{l}\text { Frewer } \\
(2000)\end{array}$ & $\begin{array}{l}\text { framework for evaluating } \\
\text { methods and uses this to } \\
\text { assess }\end{array}$ & & $\begin{array}{l}\text { early involvement; influence; transparency } \\
\text { Process criteria: resource accessibility; task definition; } \\
\text { structured decision making; cost-effectiveness }\end{array}$ & $\begin{array}{l}\text { environmental factors will interact } \\
\text { with the characteristics of a method to } \\
\text { determine effectiveness }\end{array}$ & $\begin{array}{l}\text { argumentat } \\
\text { ion: no } \\
\text { empirical } \\
\text { prove }\end{array}$ \\
\hline 7 & $\begin{array}{l}\text { Webler and } \\
\text { Tuler (2000) }\end{array}$ & $\begin{array}{l}\text { Testing the theoretical } \\
\text { criteria of } 1995\end{array}$ & $\begin{array}{l}\text { Case study, } 49 \text { open- } \\
\text { ended interviews }\end{array}$ & $\begin{array}{l}\text { Fairness and Competence } \\
\text { From interviewees: Access to the process; Power to } \\
\text { influence process and outcomes; Facilitate constructive } \\
\text { interaction; Access to information; Adequate analysis; } \\
\text { Enabling of social conditions necessary for future } \\
\text { processes }\end{array}$ & $\begin{array}{l}\text { Integrate concerns for personal } \\
\text { behaviour into the definition of } \\
\text { competence } \\
\text { study further people's normative } \\
\text { beliefs concerning participation }\end{array}$ & $\begin{array}{l}\text { Forest } \\
\text { policy }\end{array}$ \\
\hline 8 & \begin{tabular}{|l|} 
Leach and \\
Pelkey (2001)
\end{tabular} & $\begin{array}{l}\text { review of the empirical } \\
\text { literature on factors } \\
\text { affecting conflict resolution } \\
\text { in watershed partnerships }\end{array}$ & $\begin{array}{l}\text { Systematic review of } \\
37 \text { studies }\end{array}$ & $\begin{array}{l}\text { Explorative investigation: } 210 \text { distinct conclusion about } \\
\text { what makes watershed partnerships succeed and fail, } \\
\text { grouped together in } 28 \text { groups or themes }\end{array}$ & $\begin{array}{l}\text { Maintenance of a balance between } \\
\text { the Partnership's resources and its } \\
\text { scope of activities; pursuit of a flexible } \\
\text { and informal process; various ADR } \\
\text { framework variables; and various IAD } \\
\text { framework variables. }\end{array}$ & $\begin{array}{l}\text { Only USA, } \\
\text { Australia } \\
\text { and Canada }\end{array}$ \\
\hline 9 & $\begin{array}{l}\text { Beierle and } \\
\text { Cayford } \\
(2002)\end{array}$ & $\begin{array}{l}\text { Evaluation of public } \\
\text { participation }\end{array}$ & $\begin{array}{l}\text { Case survey (239 } \\
\text { cases in } \\
\text { environmental } \\
\text { decision making )USA }\end{array}$ & $\begin{array}{l}\text { Five 'social goals' for public participation: Incorporating } \\
\text { public values into decisions; Improving the substantive } \\
\text { quality of decisions; Resolving conflict among competing } \\
\text { interests; Building trust in institutions; Educating and } \\
\text { informing the public, larger political landscape, historical } \\
\text { context }\end{array}$ & $\begin{array}{l}\text { More-intensive mechanisms generally } \\
\text { are more successful than less-intensive } \\
\text { mechanism. Processes in which } \\
\text { agencies are responsive, participants } \\
\text { are motived, the quality of } \\
\text { deliberation is high, and participants } \\
\text { have at least a moderate degree of } \\
\text { control over the process }\end{array}$ & Only USA \\
\hline 10 & $\begin{array}{l}\text { Beierle } \\
(2002)\end{array}$ & $\begin{array}{l}\text { Describes a systematic } \\
\text { analysis of how } \\
\text { stakeholder processes } \\
\text { have affected the quality } \\
\text { of en-vironmental } \\
\text { decisions }\end{array}$ & $\begin{array}{l}\text { Case survey ( } 239 \\
\text { cases of public } \\
\text { participation in } \\
\text { environmental de- } \\
\text { cision making) USA }\end{array}$ & $\begin{array}{l}\text { Cost-effectiveness; joint gains among parties; contribution } \\
\text { of innovative ideas, useful analysis or new information; } \\
\text { access to scientific information and expertise }\end{array}$ & $\begin{array}{l}\text { more intensive forms of stakeholder } \\
\text { involvement are more likely to } \\
\text { produce higher-quality decisions. }\end{array}$ & Only USA \\
\hline 11 & $\begin{array}{l}\text { Leach et al. } \\
(2002)\end{array}$ & $\begin{array}{l}\text { Systematically measuring } \\
\text { multiple dimensions of } \\
\text { success for multiple } \\
\text { stakeholder partnerships }\end{array}$ & $\begin{array}{l}\text { Case study of } 44 \\
\text { watershed } \\
\text { partnerships in } \\
\text { California and } \\
\text { Washington: } 157 \\
\text { interviews and } 770 \\
\text { surveys } \\
\end{array}$ & $\begin{array}{l}\text { Perceived effects of the partnership on specific problems } \\
\text { in the watershed; perceived effects of the partnership on } \\
\text { human and social capital; the extent of agreement } \\
\text { reached among the stakeholders; implementation of } \\
\text { restoration projects; monitoring projects; and education } \\
\text { and outreach projects }\end{array}$ & $\begin{array}{l}\text { Positive relationship between each of } \\
\text { the evaluation criteria and the age of } \\
\text { the partnerships. Recommendation } \\
\text { how to assess }\end{array}$ & $\begin{array}{l}\text { Only USA } \\
\text { and water } \\
\text { partnership } \\
\text { s }\end{array}$ \\
\hline 12 & Newig (2007) & $\begin{array}{l}\text { Explore which conditions } \\
\text { and which modes of } \\
\text { participation affect } \\
\text { outcome effectiveness - as }\end{array}$ & Theory & $\begin{array}{l}\text { Context: Problem structure, Actors, Social Structure } \\
\text { Process: process design, process realisation } \\
\text { Results: direct results of the participation process, } \\
\text { substantive output and outcome }\end{array}$ & Methodological recommendations & $\begin{array}{l}\text { Only } \\
\text { theoretical }\end{array}$ \\
\hline
\end{tabular}




\begin{tabular}{|c|c|c|c|c|c|c|}
\hline No & Reference & Purpose of the study & Methods & Evaluation/Success Criteria & Conclusions & Limitations \\
\hline & & $\begin{array}{l}\text { measured by the } \\
\text { achievement of a given } \\
\text { environmental goal - in } \\
\text { which manner }\end{array}$ & & & & \\
\hline 13 & Reed (2008) & $\begin{array}{l}\text { Aims to examine evidence } \\
\text { for the claims that have } \\
\text { been made for and against } \\
\text { stakeholder participation } \\
\text { and, on this basis, to } \\
\text { identify suggestions for } \\
\text { best practice participation. }\end{array}$ & Literature Review & $\begin{array}{l}\text { Aiming at empowerment, equity, trust and learning; } \\
\text { participation should as early as possible and throughout } \\
\text { the process, representing relevant stakeholders } \\
\text { systematically; clear objectives from the outset, highly } \\
\text { skilled facilitation; integration of local and scientific } \\
\text { knowledges (providing a more comprehensive } \\
\text { understanding of complex and dynamic natural systems } \\
\text { and processes); institutionalised stakeholder participation } \\
\text { (creating organisational cultures that can facilitate } \\
\text { processes where goals are negotiated and outcomes are } \\
\text { necessarily uncertain) }\end{array}$ & $\begin{array}{l}\text { Participatory processes may seem very } \\
\text { risky, but there is growing evidence } \\
\text { that if well designed, these perceived } \\
\text { risks may be well worth taking. }\end{array}$ & $\begin{array}{l}\text { Review, not } \\
\text { clear how } \\
\text { literature } \\
\text { were } \\
\text { selected }\end{array}$ \\
\hline 14 & $\begin{array}{l}\text { Burgess and } \\
\text { Clark (2009) }\end{array}$ & $\begin{array}{l}\text { Systematic elicitation of } \\
\text { evaluative criteria from a } \\
\text { panel of practitioners }\end{array}$ & $\begin{array}{l}\text { Multi-Criteria } \\
\text { Mapping with } 17 \\
\text { practitioners, UK }\end{array}$ & $\begin{array}{l}7 \text { options of stakeholder processes } \\
7 \text { appraisal criteria: Learning, Productivity; Transparency, } \\
\text { Supportiveness; Openness; Respectfulness; Efficiency }\end{array}$ & $\begin{array}{l}\text { What works well in one context will } \\
\text { not necessarily do so in another. } \\
\text { Meanings of criteria can vary } \\
\text { substantially }\end{array}$ & $\begin{array}{l}\text { Limited } \\
\text { number of } \\
\text { Interviewee } \\
\text { s of one } \\
\text { region?! } \\
\end{array}$ \\
\hline 15 & $\begin{array}{l}\text { Peterson et } \\
\text { al. (2010) }\end{array}$ & $\begin{array}{l}\text { Investigate interaction } \\
\text { between participation and } \\
\text { its surrounding socio- } \\
\text { cultural environment }\end{array}$ & $\begin{array}{l}\text { Case Studies Brazil } \\
\text { and Uganda }\end{array}$ & & $\begin{array}{l}\text { In identifying specific ways that } \\
\text { participatory discussions proceed, } \\
\text { through pre-meetings, alliances, non- } \\
\text { linguistic cues and norms of } \\
\text { interaction, it becomes clear that the } \\
\text { socio-cultural context plays a large role } \\
\text { in organizing interactions. }\end{array}$ & $\begin{array}{l}\text { Highlighting } \\
\text { the } \\
\text { situation of } \\
\text { poor } \\
\text { people to } \\
\text { participate. } \\
\text { Only } \\
\text { observation } \\
\text { s } \\
\end{array}$ \\
\hline 16 & $\begin{array}{l}\text { Newig et al. } \\
\text { (2011) }\end{array}$ & $\begin{array}{l}\text { Does participation foster } \\
\text { sustainable development }\end{array}$ & Theory & $\begin{array}{l}\text { Empathy; Enabling and supporting socio-cultural } \\
\text { environment, local common goods can be managed in a } \\
\text { sustainable fashion }\end{array}$ & $\begin{array}{l}\text { Theoretically not able to answer } \\
\text { whether participation fosters } \\
\text { sustainable development }\end{array}$ & Theory \\
\hline 17 & $\begin{array}{l}\text { Yandle et al. } \\
(2011)\end{array}$ & $\begin{array}{l}\text { What is the role of trust in } \\
\text { an individual's decision to } \\
\text { participate }\end{array}$ & $\begin{array}{l}\text { Survey (144), New } \\
\text { Zealand }\end{array}$ & $\begin{array}{l}\text { Participation in Resource Management Activities } \\
\text { Trust in Other Fishery Participants } \\
\text { Additional Variables }\end{array}$ & $\begin{array}{l}\text { Too much and too little trust is both } \\
\text { negative correlated with participation }\end{array}$ & $\begin{array}{l}\text { Only fishery } \\
\text { in New } \\
\text { Zealand }\end{array}$ \\
\hline 18 & $\begin{array}{l}\text { Carr et al. } \\
(2012)\end{array}$ & $\begin{array}{l}\text { To organise existing } \\
\text { approaches for evaluating } \\
\text { participation, to assess } \\
\text { their usefulness, and } \\
\text { provide information and } \\
\text { guidance on the methods }\end{array}$ & Literature review & $\begin{array}{l}\text { Process Evaluation: Accountable discourse; delegation; } \\
\text { responsible leadership; cost-effectiveness; support; } \\
\text { deadlines, milestones and rewards; dialogue; facilitation; } \\
\text { knowledge inclusion; access to information and meetings; } \\
\text { ground rules and task definition; legitimate decision } \\
\text { making; representation; timing of involvement; promote }\end{array}$ & $\begin{array}{l}\text { Majority of reviewed literature view } \\
\text { participation positively: only a few } \\
\text { studies show resource management } \\
\text { benefits from participation, no studies } \\
\text { have proved negative link between } \\
\text { participation and water management. }\end{array}$ & $\begin{array}{l}\text { Only water } \\
\text { resource } \\
\text { manageme } \\
\text { nt, no } \\
\text { explanation } \\
\text { how }\end{array}$ \\
\hline
\end{tabular}




\begin{tabular}{|c|c|c|c|c|c|c|}
\hline No & Reference & Purpose of the study & Methods & Evaluation/Success Criteria & \begin{tabular}{|c|} 
Conclusions \\
\end{tabular} & Limitations \\
\hline & & used. & & $\begin{array}{l}\text { equal power } \\
\text { Intermediary outcomes: Interaction and network } \\
\text { development; trust; agreements are reached and plans } \\
\text { are developed; end to a stalemate; innovation; } \\
\text { institutional change; new organisations are created or } \\
\text { developed; shared knowledge and information } \\
\text { Resource management outcomes: Ecological } \\
\text { improvement; economic improvement; implementation } \\
\text { of an accepted plan; human health and well-being } \\
\text { improvement; reduction in conflict }\end{array}$ & $\begin{array}{l}\text { Many uncertainties remain about role } \\
\text { of participation. Evaluation poses } \\
\text { challenges. Proposing a greater focus } \\
\text { on intermediate outcomes. }\end{array}$ & $\begin{array}{l}\text { literature } \\
\text { was } \\
\text { identified }\end{array}$ \\
\hline 19 & $\begin{array}{l}\text { Palm and } \\
\text { Thoresson } \\
(2014)\end{array}$ & $\begin{array}{l}\text { Discuss how participation } \\
\text { approaches has influenced } \\
\text { the range of goals } \\
\text { implemented }\end{array}$ & $\begin{array}{l}\text { Comparison of } 4 \text { case } \\
\text { studies, ( } 86 \\
\text { interviews and } \\
\text { document analysis), } \\
\text { Sweden } \\
\end{array}$ & $\begin{array}{l}\text { Deliberative participation approach, collective learning } \\
\text { participation approach, policy-driven participation }\end{array}$ & $\begin{array}{l}\text { Different participation approaches } \\
\text { have different implications for the } \\
\text { acceptance and implementation of } \\
\text { climate and energy strategies }\end{array}$ & $\begin{array}{l}\text { Focus on } \\
\text { the role of } \\
\text { Country } \\
\text { Administrat } \\
\text { ive Boards } \\
\end{array}$ \\
\hline 20 & $\begin{array}{l}\text { Parés et al. } \\
(2015)\end{array}$ & $\begin{array}{l}\text { Analyses the consequences } \\
\text { of the deliberation and } \\
\text { explores the causes of its } \\
\text { strengths and its } \\
\text { weaknesses }\end{array}$ & $\begin{array}{l}\text { Case Study WFD } \\
\text { Catalonia, Spain: } \\
\text { textual analysis, } \\
\text { quantitative } \\
\text { indicators, interviews }\end{array}$ & $\begin{array}{l}\text { quantitative indicators: number of people and } \\
\text { stakeholders involved in the process, the number of } \\
\text { sessions, the number of proposals developed, accepted } \\
\text { and rejected } \\
\text { Specific decision, inclusiveness, transparent, open to } \\
\text { everyone, effective, mutual respect }\end{array}$ & $\begin{array}{l}\text { To summarize, we could state that the } \\
\text { participants are satisfied with the } \\
\text { process but unsatisfied with its results }\end{array}$ & $\begin{array}{l}\text { Low } \\
\text { diversity of } \\
\text { interview } \\
\text { partners }\end{array}$ \\
\hline 21 & $\begin{array}{l}\text { Schweizer et } \\
\text { al. (2016) }\end{array}$ & $\begin{array}{l}\text { Investigates the prospects } \\
\text { of participation and offers } \\
\text { the concept of analytic- } \\
\text { deliberative discourse as a } \\
\text { guiding model for } \\
\text { implementation } \\
\end{array}$ & Theory & Social cohesion, Resilience, Efficiency, Effectiveness & $\begin{array}{l}\text { legal frameworks for infrastructure } \\
\text { planning and decision-making should } \\
\text { be based on Practical experience with } \\
\text { as well as social science evaluation of } \\
\text { participation }\end{array}$ & policy note \\
\hline 22 & $\begin{array}{l}\text { Schroeter et } \\
\text { al. (2016) }\end{array}$ & $\begin{array}{l}\text { How can one measure and } \\
\text { evaluate the effects of a } \\
\text { participation process } \\
\text { determining its quality? } \\
\end{array}$ & $\begin{array}{l}\text { Review and case } \\
\text { study survey, } \\
\text { Germany }\end{array}$ & $\begin{array}{l}8 \text { Dimensions of Measurement: Expectancy; } \\
\text { Transparency; Acceptance; Fairness, Effectiveness, } \\
\text { Efficiency, Own Impact; Satisfaction }\end{array}$ & $\begin{array}{l}\text { Criteria have to be adapted to the } \\
\text { structure given by the case study in } \\
\text { order to maximize the quality of the } \\
\text { evaluation }\end{array}$ & $\begin{array}{l}\text { Only one } \\
\text { case }\end{array}$ \\
\hline 23 & $\begin{array}{l}\text { Ernst et al. } \\
(2017)\end{array}$ & $\begin{array}{l}\text { Analysis how a science- } \\
\text { practice dialogue can } \\
\text { improve the understanding } \\
\text { of transformation } \\
\text { processes towards low- } \\
\text { carbon societies }\end{array}$ & $\begin{array}{l}\text { Dialogue process in } \\
\text { North Rhine- } \\
\text { Westphalia, Survey }\end{array}$ & $\begin{array}{l}\text { empowerment, fairness, legitimacy, transparency, } \\
\text { efficiency, effectiveness, network-building, facilitation }\end{array}$ & $\begin{array}{l}\text { Facilitators highly impact dialogue } \\
\text { processes. }\end{array}$ & $\begin{array}{l}\text { Findings } \\
\text { from a } \\
\text { region of } \\
\text { Germany, }\end{array}$ \\
\hline 24 & \begin{tabular}{|l} 
Cuppen \\
$(2018)$
\end{tabular} & $\begin{array}{l}\text { Discussing the value of } \\
\text { social conflict }\end{array}$ & Theory & Social conflict & Further research is necessary. & $\begin{array}{l}\text { Only } \\
\text { theoretical }\end{array}$ \\
\hline
\end{tabular}




\begin{tabular}{|c|c|c|c|c|c|c|}
\hline No & Reference & Purpose of the Study & Methods & Factors Influencing Social Learning & Conclusions & Limitations \\
\hline 1 & $\begin{array}{l}\text { Webler et al. } \\
(1995)\end{array}$ & $\begin{array}{l}\text { How participation enhance } \\
\text { social learning, application } \\
\text { of evaluation criteria }\end{array}$ & $\begin{array}{l}\text { Case study, } \\
\text { Switzerland }\end{array}$ & $\begin{array}{l}\text { Cognitive enhancement: giving detailed, but accessible } \\
\text { information on the very first day, offering citizens chances } \\
\text { to co-design the education process, combining } \\
\text { "classroom" learning with field trips, giving participants } \\
\text { chances to discuss what they learned in small groups, } \\
\text { encouraging them to put their new knowledge to work in } \\
\text { impact assessment activities; moral development: } \\
\text { structure(familiar atmosphere, regular meetings), rules } \\
\text { and facilitation, activities (connecting theory with reality), } \\
\text { trust; Obstacles to social learning: missing confidence in } \\
\text { one's impact }\end{array}$ & $\begin{array}{l}\text { We believe that a focus on achieving } \\
\text { the criteria for social learning } \\
\text { combined with the criteria for fairness } \\
\text { and competence will result in public } \\
\text { participation experiences that are } \\
\text { widely viewed as successful. }\end{array}$ & $\begin{array}{l}\text { Single case } \\
\text { study of a } \\
\text { lengthy and } \\
\text { intensive } \\
\text { participatio } \\
\text { n process }\end{array}$ \\
\hline 2 & $\begin{array}{l}\text { Knoepfel and } \\
\text { Kissling-Näf } \\
(1998)\end{array}$ & $\begin{array}{l}\text { Studying the way in which } \\
\text { interorganisational } \\
\text { learning processes unfold } \\
\text { in different policy fields }\end{array}$ & $\begin{array}{l}\text { Meta-analysis of } 28 \\
\text { case studies, } \\
\text { Switzerland }\end{array}$ & $\begin{array}{l}\text { Development of shared understanding about instruments } \\
\text { and processes during the implementation phase; Number } \\
\text { and type of actors, the most relevant representatives; } \\
\text { Kind of interaction; exchange of resources indicate } \\
\text { collective learning; aim of process; access to knowledge; } \\
\text { formalised arrangements for the production and } \\
\text { dissemination of knowledge }\end{array}$ & Identification of 5 learning patterns; & $\begin{array}{l}\text { No direct } \\
\text { measureme } \\
\text { nt of } \\
\text { learning }\end{array}$ \\
\hline 3 & \begin{tabular}{|l|} 
Schusler et al. \\
$(2003)$
\end{tabular} & $\begin{array}{l}\text { Investigate social learning } \\
\text { and its role in developing } \\
\text { collaborative management }\end{array}$ & $\begin{array}{l}\text { Case study, } \\
\text { telephone } \\
\text { interviews, USA }\end{array}$ & $\begin{array}{l}\text { Democratic structure, open communication, diverse } \\
\text { participation, multiple sources of knowledge, extended } \\
\text { engagement, unrestrained thinking, constructive conflict, } \\
\text { facilitation }\end{array}$ & $\begin{array}{l}\text { The need for social learning as an } \\
\text { ongoing process in which participants } \\
\text { can assess the quality of information } \\
\text { shared and reconcile } \\
\text { misunderstandings, as well as adapt } \\
\text { management goals and collaborative } \\
\text { initiatives as they gather new } \\
\text { information and learn from } \\
\text { experience. } \\
\end{array}$ & $\begin{array}{l}\text { Single case } \\
\text { study }\end{array}$ \\
\hline 4 & $\begin{array}{l}\text { Brown et al. } \\
(2005)\end{array}$ & $\begin{array}{l}\text { Answering questions } \\
\text { regarding social learning } \\
\text { formulated at the } \\
\text { beginning of the book }\end{array}$ & $\begin{array}{l}\text { Concluding book } \\
\text { section, summary of } \\
\text { empirical studies } \\
\text { presented in the } \\
\text { book }\end{array}$ & $\begin{array}{l}\text { Reflexive processes to critically consider actions, } \\
\text { assumptions and values; interdependencies and } \\
\text { interrelationships of social and ecological systems; } \\
\text { integrating ideas and actions across social boundaries; } \\
\text { whole community; participatory and adaptive process; } \\
\text { takes into account power relations, }\end{array}$ & $\begin{array}{l}\text { Principles of social learning for } \\
\text { environmental management. }\end{array}$ & \\
\hline 5 & $\begin{array}{l}\text { Tippett et al. } \\
(2005)\end{array}$ & $\begin{array}{l}\text { Presentation of project } \\
\text { concept and early findings } \\
\text { from case studies }\end{array}$ & $\begin{array}{l}\text { Case studies in } 9 \\
\text { European countries, } \\
\text { water }\end{array}$ & $\begin{array}{l}\text { Provision of sufficient time, involving stakeholders' early } \\
\text { and careful attention to process management. Techniques } \\
\text { to help participants recognise and respect different } \\
\text { viewpoints. Making implicit assumptions visible to } \\
\text { different stakeholders can enable the use of this } \\
\text { understanding to craft solutions acceptable to the }\end{array}$ & $\begin{array}{l}\text { Identified factors fostering and } \\
\text { hindering social learning }\end{array}$ & $\begin{array}{l}\text { Preliminary } \\
\text { findings }\end{array}$ \\
\hline
\end{tabular}




\begin{tabular}{|c|c|c|c|c|c|c|}
\hline No & Reference & Purpose of the Study & Methods & $\begin{array}{c}\text { Factors Influencing Social Learning } \\
\end{array}$ & Conclusions & Limitations \\
\hline & & & & $\begin{array}{l}\text { involved parties. Methods that develop participants' } \\
\text { critical capacity enable adaptation to changing } \\
\text { circumstances. Participatory processes were highly } \\
\text { influenced by prior experience with participation and } \\
\text { cultural and institutional contexts. }\end{array}$ & & \\
\hline 6 & $\begin{array}{l}\text { van de } \\
\text { Kerkhof and } \\
\text { Wieczorek } \\
\text { (2005) }\end{array}$ & $\begin{array}{l}\text { Make methodological } \\
\text { suggestions on how TMgt } \\
\text { process, could be } \\
\text { approached so as to } \\
\text { improve the learning } \\
\text { effect. }\end{array}$ & $\begin{array}{l}\text { Case study, Dutch } \\
\text { climate options for } \\
\text { the long-term }\end{array}$ & $\begin{array}{l}\text { Independent facilitation; balance between homogeny and } \\
\text { heterogenic participants; not only factual and empirical } \\
\text { knowledge but also normative aspects of the problem; } \\
\text { commitment of participants; information provided in the } \\
\text { process should be of scientific quality but communicated } \\
\text { in an understandable and accessible way, which also } \\
\text { makes uncertainties and controversies explicit to increase } \\
\text { competence; fairness }\end{array}$ & $\begin{array}{l}\text { Should be an open and dynamic } \\
\text { network, but a facilitator is needed. }\end{array}$ & $\begin{array}{l}\text { Focused } \\
\text { only on the } \\
\text { first } \\
\text { process } \\
\text { phases, no } \\
\text { measuring } \\
\text { of social } \\
\text { learning } \\
\text { and its } \\
\text { causes } \\
\end{array}$ \\
\hline 7 & Petts (2006) & $\begin{array}{l}\text { How a deliberative process } \\
\text { can capitalize on local } \\
\text { knowledge and lead to } \\
\text { shared (expert and public) } \\
\text { learning and } \\
\text { understanding }\end{array}$ & Case study & $\begin{array}{l}\text { Recruitment of representative interests; Active } \\
\text { Facilitation; Collaborative Framing; Optimizing Interaction; } \\
\text { Managing the Unexpected; }\end{array}$ & $\begin{array}{l}\text { Importance of creating and managing } \\
\text { the right conditions to support } \\
\text { learning. Organizational or social } \\
\text { learning may be a more lasting impact } \\
\text { of any engagement effort than the } \\
\text { actual plan or project delivered. }\end{array}$ & $\begin{array}{l}\text { One case } \\
\text { study } \\
\text { analysed } \\
\text { from the } \\
\text { perspective } \\
\text { of an } \\
\text { facilitator }\end{array}$ \\
\hline 8 & $\begin{array}{l}\text { Jiggins et al. } \\
(2007)\end{array}$ & $\begin{array}{l}\text { The role and meaning of } \\
\text { 'knowledge' as a driver of } \\
\text { transformational change. }\end{array}$ & $\begin{array}{l}\text { Case studies and } \\
\text { policy analyses, } \\
\text { Netherlands }\end{array}$ & $\begin{array}{l}\text { Conflict and confrontation among stakeholders; discovery } \\
\text { of interdependence among stakeholders; development of } \\
\text { social spaces where stakeholders could encounter each } \\
\text { other in shared actions; and the role of facilitators and } \\
\text { process leaders in helping stakeholders to go forward. }\end{array}$ & & $\begin{array}{l}\text { Focus on } \\
\text { knowledge } \\
\text { and thus } \\
\text { not } \\
\text { measuring } \\
\text { social } \\
\text { learning }\end{array}$ \\
\hline 9 & $\begin{array}{l}\text { Mostert et al. } \\
(2007)\end{array}$ & $\begin{array}{l}\text { Evidence of social learning } \\
\text { processes and outcomes } \\
\text { and attempt to identify } \\
\text { factors that foster or } \\
\text { hinder social learning } \\
\end{array}$ & $\begin{array}{l}10 \text { case studies, } \\
\text { interviews, } \\
\text { document analysis, } \\
\text { observation, Water } \\
\text { Governance, Europe } \\
\end{array}$ & $\begin{array}{l}\text { The role of stakeholder involvement, politics and } \\
\text { institutions, opportunities for interaction, motivation and } \\
\text { skills of leaders and facilitators, openness and } \\
\text { transparency, representativeness, framing and reframing, } \\
\text { resources }\end{array}$ & $\begin{array}{l}\text { When a truly participatory approach } \\
\text { took place, this resulted in benefits for } \\
\text { the stakeholders involved and for the } \\
\text { environment. }\end{array}$ & \\
\hline 10 & $\begin{array}{l}\text { Pahl-Wostl et } \\
\text { al. (2007) }\end{array}$ & $\begin{array}{l}\text { Social learning concept as } \\
\text { foundation for empirical } \\
\text { research project }\end{array}$ & Theory & $\begin{array}{l}\text { Networks or "communities of practice"; the governance } \\
\text { structure in which they are embedded: institutional } \\
\text { settings that guarantee some degree of stability; certainty } \\
\text { without being rigid and inflexible. }\end{array}$ & & $\begin{array}{l}\text { Empirical } \\
\text { findings are } \\
\text { presented } \\
\text { in Mostert } \\
\text { et al. } 2007 \\
\end{array}$ \\
\hline 11 & Wiek (2007) & $\begin{array}{l}\text { Discuss the main } \\
\text { challenges observed, }\end{array}$ & $\begin{array}{l}\text { Review of } \\
\text { transdisciplinary }\end{array}$ & $\begin{array}{l}\text { Four challenges of joint knowledge generation: } \\
\text { confounded agendas, }\end{array}$ & $\begin{array}{l}\text { A new type of mediated negotiation, } \\
\text { so-called 'epistemediation', is }\end{array}$ & $\begin{array}{l}\text { Review, } \\
\text { focus on TD }\end{array}$ \\
\hline
\end{tabular}




\begin{tabular}{|c|c|c|c|c|c|c|}
\hline No & Reference & Purpose of the Study & Methods & Factors Influencing Social Learning & Conclusions & Limitations \\
\hline & & $\begin{array}{l}\text { focusing on the inter- } \\
\text { individual interactions in } \\
\text { knowledge generation, } \\
\text { such as information, } \\
\text { consultation, collaboration, } \\
\text { and negotiation }\end{array}$ & research & $\begin{array}{l}\text { separate data philosophies, } \\
\text { reluctance to face exposure } \\
\text { co-existing values }\end{array}$ & proposed & \\
\hline 12 & $\begin{array}{l}\text { Armitage et } \\
\text { al. (2008) }\end{array}$ & $\begin{array}{l}\text { Examine five dimensions of } \\
\text { the learning paradox in the } \\
\text { context of adaptive co- } \\
\text { management, where the } \\
\text { learning and linking } \\
\text { functions of governance } \\
\text { are stressed }\end{array}$ & $\begin{array}{l}\text { Literature review, } \\
\text { cumulative insights } \\
\text { from resource } \\
\text { management cases, } \\
\text { Water, Canada, } \\
\text { Southeast Asia. }\end{array}$ & Capacity Building, power relation, social networks & $\begin{array}{l}\text { Learning is neither value free nor } \\
\text { politically neutral. Attention to the } \\
\text { formal and informal connections } \\
\text { which at once shape, and are an } \\
\text { outcome of, power relations is } \\
\text { necessary }\end{array}$ & $\begin{array}{l}\text { Only } \\
\text { observation } \\
\text {, no } \\
\text { empirical } \\
\text { data }\end{array}$ \\
\hline 13 & $\begin{array}{l}\text { Borowski et } \\
\text { al. (2008) }\end{array}$ & $\begin{array}{l}\text { How spatial misfits } \\
\text { between participatory and } \\
\text { decision-making } \\
\text { institutions impede social } \\
\text { learning, and therefore, } \\
\text { the success of RBMP }\end{array}$ & $\begin{array}{l}\text { Case studies, Water, } \\
\text { Germany, France }\end{array}$ & $\begin{array}{l}\text { An interface that successfully facilitates SL processes } \\
\text { requires financial and legal capacities, including the } \\
\text { mandate to deal with certain tasks. The interface not only } \\
\text { needs to have the mandate for communicating with } \\
\text { stakeholders, establishing multi-party interaction, and } \\
\text { facilitating information flow. It also needs a close link to } \\
\text { the decision-making institutions to ensure that the gains } \\
\text { and incentives are sufficient for stakeholders to engage in } \\
\text { them }\end{array}$ & $\begin{array}{l}\text { Even though a strong interface } \\
\text { between participatory and decision- } \\
\text { making institutions will strongly } \\
\text { support SL in participatory processes, } \\
\text { it may not be able to solve all } \\
\text { challenges, such as language barriers } \\
\text { to informal interactions }\end{array}$ & $\begin{array}{l}\text { No direct } \\
\text { measureme } \\
\text { nt of social } \\
\text { learning }\end{array}$ \\
\hline 14 & $\begin{array}{l}\text { Gohl and } \\
\text { Wüst (2008) }\end{array}$ & $\begin{array}{l}\text { Are participation processes } \\
\text { new places to foster } \\
\text { lifelong learning }\end{array}$ & $\begin{array}{l}2 \text { case studies, } \\
\text { Germany }\end{array}$ & 8 theses & $\begin{array}{l}\text { Participation processes are important } \\
\text { learning places of society. Their design } \\
\text { should not only target (political) } \\
\text { decisions, but must also foster } \\
\text { common learning process. }\end{array}$ & $\begin{array}{l}\text { Only } \\
\text { observation } \\
\text {, no survey }\end{array}$ \\
\hline 15 & $\begin{array}{l}\text { Kumler and } \\
\text { Lemos (2008) }\end{array}$ & $\begin{array}{l}\text { Investigation of social } \\
\text { learning as both enabling } \\
\text { implementation of water } \\
\text { reform institutions and } \\
\text { being enabled by } \\
\text { implementation. }\end{array}$ & $\begin{array}{l}\text { Case study, mixed } \\
\text { method approach: } \\
\text { semi structured } \\
\text { interviews, } \\
\text { observation (survey), } \\
\text { water, Brazil } \\
\end{array}$ & $\begin{array}{l}\text { The changing nature of state-society relations, the } \\
\text { institutional structure, the role of actors and networks, } \\
\text { and actor trust and buy-in to the system have all } \\
\text { enhanced social learning. }\end{array}$ & $\begin{array}{l}\text { Social learning has been critical in } \\
\text { facilitating reform implementation so } \\
\text { far, and will likely continue to be an } \\
\text { important factor for the future } \\
\text { sustainability of the new management } \\
\text { system. }\end{array}$ & $\begin{array}{l}\text { Only a case, } \\
\text { no direct } \\
\text { measureme } \\
\text { nt of } \\
\text { learning?! }\end{array}$ \\
\hline 16 & $\begin{array}{l}\text { Van Bommel } \\
\text { et al. (2009) }\end{array}$ & $\begin{array}{l}\text { Investigate the potential of } \\
\text { the social learning } \\
\text { approach for solving } \\
\text { complex resource } \\
\text { dilemmas }\end{array}$ & $\begin{array}{l}\text { Case study, media } \\
\text { analysis, archive } \\
\text { research, open } \\
\text { interviews, meetings, } \\
\text { water management, } \\
\text { Netherlands }\end{array}$ & $\begin{array}{l}\text { Power relations, inclusiveness, joint problem framing vs. } \\
\text { reducing complexity, interdependence }\end{array}$ & $\begin{array}{l}\text { Our findings show that, although the } \\
\text { platform aimed for open dialogue and } \\
\text { at first sight appeared to meet the } \\
\text { conditions, social learning was not } \\
\text { achieved and the negotiations } \\
\text { stagnated because of disagreement, } \\
\text { frustration and distrust. }\end{array}$ & $\begin{array}{l}\text { Single case } \\
\text { study }\end{array}$ \\
\hline 17 & Brummel et & Whether policy-mandated & 3 case studies, & Policy.-mandated collaboration set the institutional & Policy-mandated collaboration can be & Participatio \\
\hline
\end{tabular}




\begin{tabular}{|c|c|c|c|c|c|c|}
\hline No & Reference & Purpose of the Study & Methods & Factors Influencing Social Learning & Conclusions & Limitations \\
\hline & al. (2010) & $\begin{array}{l}\text { collaboration can } \\
\text { encourage learning, } \\
\text { transformation, and joint } \\
\text { action amongst planning } \\
\text { partners. }\end{array}$ & $\begin{array}{l}\text { interviews, } \\
\text { document analysis, } \\
\text { wildfire protection } \\
\text { planning, USA }\end{array}$ & $\begin{array}{l}\text { context, extended engagement, diverse stakeholder } \\
\text { representation, facilitation, dominance of agency } \\
\text { representatives, openness }\end{array}$ & $\begin{array}{l}\text { a convening element and may set the } \\
\text { structural context for social learning at } \\
\text { the local level. However, local context } \\
\text { and collaborative process are crucial } \\
\text { and policy must be realised at this } \\
\text { level through leadership, skilled } \\
\text { facilitation, dedication to expanding } \\
\text { participant pools to non-traditional }\end{array}$ & $\mathrm{n}$ of experts \\
\hline 18 & Cundill (2010) & $\begin{array}{l}\text { explores the characteristics } \\
\text { of processes that promote } \\
\text { learning in adaptive co- } \\
\text { management, and also } \\
\text { aims to test a methodology } \\
\text { for monitoring these in a } \\
\text { collaborative way }\end{array}$ & $\begin{array}{l}\text { 3case studies, focus } \\
\text { group workshop, } \\
\text { semi structured } \\
\text { discussions }\end{array}$ & $\begin{array}{l}\text { Trust building, groups of common interest, economic or } \\
\text { other incentives for collective action, security of tenure } \\
\text { over the resources of concern, a perceived value in } \\
\text { sharing information, willingness to engage in collaborative } \\
\text { decision making, sufficient funding to enable practical } \\
\text { action and experimentation, social networks that allow } \\
\text { effective information flow, effective local leadership/ } \\
\text { 'honest broker' }\end{array}$ & $\begin{array}{l}\text { For learning to be effective, a balance } \\
\text { needs to be sought between } \\
\text { maintaining key individuals within the } \\
\text { system, preventing rigidity and } \\
\text { vulnerability when this is achieved, } \\
\text { and encouraging active participation } \\
\text { within communities of practice. }\end{array}$ & Experiment \\
\hline 19 & $\begin{array}{l}\text { Garmendia } \\
\text { and Stagl } \\
(2010)\end{array}$ & $\begin{array}{l}\text { How successful are } \\
\text { deliberative processes as } \\
\text { part of sustainability } \\
\text { appraisals in stimulating } \\
\text { social learning }\end{array}$ & $\begin{array}{l}\text { Framework } \\
\text { development, tested } \\
\text { within } 3 \text { case studies, } \\
\text { questionnaire, } \\
\text { Austria, UK, Spain }\end{array}$ & $\begin{array}{l}\text { Wider opportunity for interaction and deliberation, i.e. } \\
\text { more time for discussion }\end{array}$ & $\begin{array}{l}\text { Social learning does happen in } \\
\text { participatory workshops, but (1) to a } \\
\text { lesser extent than expected and (2) } \\
\text { the depth and breadth of learning } \\
\text { depends on the workshop design, time } \\
\text { given to the process and the type of } \\
\text { participants. }\end{array}$ & \begin{tabular}{|l} 
No \\
systematic \\
analyses of \\
level of \\
learning \\
and \\
characterist \\
ics of \\
participatio \\
$\mathrm{n}$ \\
\end{tabular} \\
\hline 20 & $\begin{array}{l}\text { Huitema et } \\
\text { al. (2010) }\end{array}$ & $\begin{array}{l}\text { Assess empirically the } \\
\text { connection between public } \\
\text { participation and learning }\end{array}$ & $\begin{array}{l}\text { case studies on } \\
\text { citizens' jury, } \\
\text { Netherlands, Water }\end{array}$ & $\begin{array}{l}\text { Clarity about role of stakeholder involvement, politics and } \\
\text { institutions, opportunities for interaction, motivation and } \\
\text { skill of leaders and facilitators, openness and } \\
\text { transparency, representativeness, framing and reframing } \\
\text { (joint problem definition), resources }\end{array}$ & $\begin{array}{l}\text { We find high levels of cognitive, } \\
\text { normative, and relational levels of } \\
\text { learning for the jurors, but relatively } \\
\text { low levels of learning for policy makers }\end{array}$ & Experiment \\
\hline 21 & $\begin{array}{l}\text { Pohl et al. } \\
(2010)\end{array}$ & $\begin{array}{l}\text { Analysis of the challenges } \\
\text { that the co-product-ion of } \\
\text { know-ledge poses to the } \\
\text { researchers, and of the } \\
\text { roles in which these } \\
\text { challenges are met }\end{array}$ & $\begin{array}{l}\text { Observation of } 4 \\
\text { transdisciplinary } \\
\text { research projects, } \\
\text { involved researchers } \\
\text { in an iterative, self- } \\
\text { reflexive process }\end{array}$ & $\begin{array}{l}\text { Power: Addressing power relationships between different } \\
\text { actors } \\
\text { Integration: Ensuring that a common understanding } \\
\text { emerges } \\
\text { Sustainability: Ensuring that knowledge co-production } \\
\text { serves the purpose of sustainable development }\end{array}$ & $\begin{array}{l}\text { The intuitive assuming of specific roles } \\
\text { seemed to be clearly guided by the } \\
\text { objective of promoting and enhancing } \\
\text { knowledge co-production, based on } \\
\text { openness and the search for } \\
\text { deliberative interaction of all the } \\
\text { thought collectives involved. }\end{array}$ & $\begin{array}{l}\text { Focusing on } \\
\text { the role of } \\
\text { the } \\
\text { researcher }\end{array}$ \\
\hline 22 & $\begin{array}{l}\text { Edelenbos et } \\
\text { al. (2011) }\end{array}$ & $\begin{array}{l}\text { Describe and analyse the } \\
\text { process of co-producing } \\
\text { knowledge among experts, }\end{array}$ & $\begin{array}{l}\text { Comparison of two } \\
\text { case studies, } \\
\text { Netherlands }\end{array}$ & $\begin{array}{l}\text { Multi criteria analysis and the method of co-evaluation } \\
\text { enable the various groups to bring in their knowledge and } \\
\text { to integrate this knowledge. Specific techniques of }\end{array}$ & $\begin{array}{l}\text { It is concluded that knowledge co- } \\
\text { production between experts and } \\
\text { bureaucrats is not very problematic, }\end{array}$ & $\begin{array}{l}\text { Case } \\
\text { studies }\end{array}$ \\
\hline
\end{tabular}




\begin{tabular}{|c|c|c|c|c|c|c|}
\hline No & Reference & Purpose of the Study & Methods & Factors Influencing Social Learning & Conclusions & Limitations \\
\hline & & $\begin{array}{l}\text { bureaucrats and } \\
\text { stakeholders. }\end{array}$ & & $\begin{array}{l}\text { knowledge mobilization and exchange can be helpful to } \\
\text { realize coproduction. The way in which methods of } \\
\text { knowledge production are used and the intention of the } \\
\text { involved actors to combine and harmonize knowledge is } \\
\text { more decisive for realizing coproduced knowledge, then } \\
\text { the methods themselves. The level of interaction in the } \\
\text { method used is important for realizing coproduced } \\
\text { knowledge. }\end{array}$ & $\begin{array}{l}\text { because of discipline congruence and } \\
\text { institutionalized relations. Knowledge } \\
\text { co- production between stakeholders } \\
\text { on the one hand and experts and } \\
\text { bureaucrats on the other is more } \\
\text { problematic and leads to problems of } \\
\text { legitimacy in knowledge production } \\
\text { and decision-making. }\end{array}$ & \\
\hline 23 & $\begin{array}{l}\text { Gerlak and } \\
\text { Heikkila } \\
\text { (2011) }\end{array}$ & $\begin{array}{l}\text { Examine how the } \\
\text { framework helps diagnose } \\
\text { the specific types of } \\
\text { learning processes and } \\
\text { products that emerge in } \\
\text { this setting, as well as the } \\
\text { factors that influence these } \\
\text { learning processes. }\end{array}$ & $\begin{array}{l}\text { Survey and } \\
\text { interviews, Case } \\
\text { study, ecosystem } \\
\text { restoration program, } \\
\text { USA }\end{array}$ & $\begin{array}{l}\text { Structure: communication, coordination, control of } \\
\text { information } \\
\text { Social dynamics: influence and power of leaders } \\
\text { (participants), frequency and intensity of interaction; trust } \\
\text { one another and accept new ideas, existing social } \\
\text { networks } \\
\text { Technological and functional domain: Tools for processing } \\
\text { and storing information, task specificity } \\
\text { Exogenous factors: Political, social, physical and economic } \\
\text { changes }\end{array}$ & $\begin{array}{l}\text { Learning process is fostered by a } \\
\text { structure that accommodates diverse } \\
\text { sources of knowledge } \rightarrow \text { diverse } \\
\text { members (inclusive). Trust building } \\
\text { (shared goals). }\end{array}$ & $\begin{array}{l}\text { 'extreme } \\
\text { cases' }\end{array}$ \\
\hline 24 & $\begin{array}{l}\text { Hoverman et } \\
\text { al. (2011) }\end{array}$ & $\begin{array}{l}\text { reports on an evaluation of } \\
\text { a participatory research } \\
\text { process that was } \\
\text { conducted to develop a } \\
\text { catchment risk assessment } \\
\text { to improve natural } \\
\text { resource and water } \\
\text { management }\end{array}$ & $\begin{array}{l}\text { Case: participatory } \\
\text { research project, } \\
\text { Solomon Islands }\end{array}$ & $\begin{array}{l}\text { Carefully customized process and the use of bridging } \\
\text { individuals in the form of a respected community } \\
\text { interpreter and individuals prepared to contribute to } \\
\text { integrative discussion. }\end{array}$ & $\begin{array}{l}\text { The novelty of the participatory } \\
\text { process has clearly contributed to its } \\
\text { enthusiastic endorsement by } \\
\text { community and NGOs, unfettered at } \\
\text { this stage by a history of false starts } \\
\text { and disillusionment. }\end{array}$ & $\begin{array}{l}\text { Research } \\
\text { project } \\
\text { (experimen } \\
\text { tal) }\end{array}$ \\
\hline 25 & $\begin{array}{l}\text { Squires and } \\
\text { Renn (2011) }\end{array}$ & $\begin{array}{l}\text { Explores the concept of } \\
\text { analytical-deliberate } \\
\text { decision-making and the } \\
\text { role of social learning }\end{array}$ & $\begin{array}{l}\text { Interviews and } \\
\text { observation of } \\
\text { Fishery project, } \\
\text { England }\end{array}$ & $\begin{array}{l}\text { Diverse participation, Democratic structure, Extended } \\
\text { engagement, Multiple sources of knowledge, } \\
\text { Unrestrained thinking, Open communications, } \\
\text { Constructive conflict, facilitation support }\end{array}$ & $\begin{array}{l}\text { that it is through the communication } \\
\text { and sharing of information - and not } \\
\text { through the technology itself - that } \\
\text { new information and emergent } \\
\text { learning occurs }\end{array}$ & $\begin{array}{l}\text { Single case } \\
\text { study }\end{array}$ \\
\hline 26 & $\begin{array}{l}\text { Crona and } \\
\text { Parker (2012) }\end{array}$ & $\begin{array}{l}\text { conducting cross-case } \\
\text { comparisons aimed at } \\
\text { understanding the social } \\
\text { environmental conditions } \\
\text { under which learning in } \\
\text { such organizations does } \\
\text { and does not occur }\end{array}$ & $\begin{array}{l}\text { Case study, } \\
\text { interview, } \\
\text { documentary, and } \\
\text { observational data } \\
\text { USA }\end{array}$ & $\begin{array}{l}\text { We found that different numbers and types of social } \\
\text { interactions can have significant, independent effects on } \\
\text { the use of scientific knowledge in natural resource } \\
\text { governance. Importance of embeddedness of actors in } \\
\text { social networks of peers for knowledge utilization. } \\
\text { Boundary objects also helped to align stakeholder } \\
\text { interests and enhance learning, but only via active } \\
\text { facilitation by key liaisons brokering between the } \\
\text { divergent interests of bridging organization stakeholder } \\
\text { groups. }\end{array}$ & $\begin{array}{l}\text { manage divergent stakeholder } \\
\text { interests and navigate power } \\
\text { differentials among them to } \\
\text { successfully catalyse learning in } \\
\text { support of natural resource } \\
\text { governance }\end{array}$ & $\begin{array}{l}\text { Single case } \\
\text { study }\end{array}$ \\
\hline
\end{tabular}




\begin{tabular}{|c|c|c|c|c|c|c|}
\hline No & Reference & Purpose of the Study & Methods & Factors Influencing Social Learning & Conclusions & Limitations \\
\hline 27 & $\begin{array}{l}\text { Cuppen } \\
(2012)\end{array}$ & $\begin{array}{l}\text { how a methodology for } \\
\text { stakeholder dialogue can } \\
\text { be evaluated in terms of } \\
\text { learning }\end{array}$ & $\begin{array}{l}\text { Participatory } \\
\text { research, biomass (Q } \\
\text { methodology), } \\
\text { Netherlands }\end{array}$ & $\begin{array}{l}\text { Stakeholder selection procedure should be able to } \\
\text { address marginal perspectives and to cut across networks. } \\
\text { prevent mechanisms through which some perspectives } \\
\text { are more likely to play a role than others: small subgroups } \\
\text { were helpful in increasing speech time and opportunities } \\
\text { for all participants }\end{array}$ & $\begin{array}{l}\text { Learning does not mean that } \\
\text { participants drastically change their } \\
\text { perspective. Rather, learning means } \\
\text { that participants better understand } \\
\text { and acknowledge the diversity of } \\
\text { perspectives, which enables them to } \\
\text { use the perspectives as a structure to } \\
\text { deal with the complexity of the issue. }\end{array}$ & $\begin{array}{l}\text { Participator } \\
\text { y research } \\
\text { (experimen } \\
\text { t) }\end{array}$ \\
\hline 28 & $\begin{array}{l}\text { Muro and } \\
\text { Jeffrey (2012) }\end{array}$ & $\begin{array}{l}\text { To what extent are } \\
\text { participatory processes } \\
\text { characterized by social } \\
\text { learning? Which process } \\
\text { characteristics encourage } \\
\text { or hinder social learning? }\end{array}$ & $\begin{array}{l}\text { Postal survey from } \\
\text { two case studies in } \\
\text { Germany and } \\
\text { Ireland, Water }\end{array}$ & $\begin{array}{l}\text { Facilitation, opportunity for interaction, egalitarian } \\
\text { atmosphere, repeated meetings, process control, open } \\
\text { communication, diverse participation, unrestrained } \\
\text { thinking, information exchange }\end{array}$ & $\begin{array}{l}\text { Gaining new insides does not mean } \\
\text { altering ones' views. Social learning is } \\
\text { a multi-dimensional and dynamic } \\
\text { process and the extent to which } \\
\text { stakeholder platforms promote social } \\
\text { learning is shaped by organizational } \\
\text { arrangements and time provided for } \\
\text { the engagement process. }\end{array}$ & Case study \\
\hline 29 & $\begin{array}{l}\text { Wilner et al. } \\
\text { (2012) }\end{array}$ & $\begin{array}{l}\text { Until social learning theory } \\
\text { leans more heavily on } \\
\text { group processes of trans- } \\
\text { formative learning, } \\
\text { sustainable development } \\
\text { will elude us. }\end{array}$ & $\begin{array}{l}\text { Theory and case } \\
\text { study, five-year } \\
\text { research project, } \\
\text { Canada }\end{array}$ & $\begin{array}{l}\text { Critical reflection: Process reflection and premise } \\
\text { reflection } \\
\text { Critical reflections promotes alternative and creative } \\
\text { restructuring of our actions }\end{array}$ & $\begin{array}{l}\text { A process of systematic, critical } \\
\text { reflection is key to transformative } \\
\text { learning }\end{array}$ & $\begin{array}{l}\text { Only } \\
\text { observation } \\
\text { of one } \\
\text { research } \\
\text { project } \\
\text { (experimen } \\
\text { t) }\end{array}$ \\
\hline 30 & $\begin{array}{l}\text { Brewer } \\
(2013)\end{array}$ & $\begin{array}{l}\text { extent to which learning } \\
\text { among resource users } \\
\text { might enhance public } \\
\text { participation, sidelining } \\
\text { questions about the } \\
\text { possibility of parallel } \\
\text { learning by management } \\
\text { and policy professionals, or } \\
\text { by other groups with } \\
\text { interests in resource } \\
\text { outcomes }\end{array}$ & $\begin{array}{l}\text { Case study, } \\
\text { workshop } \\
\text { observation, } \\
\text { interviews, informal } \\
\text { conversations }\end{array}$ & $\begin{array}{l}\text { These achievements do not require large public } \\
\text { expenditures. The roundtable succeeds by staging social } \\
\text { learning events that are more intensive than those } \\
\text { encountered in the ordinary social interactions of daily } \\
\text { life. Neutral informal environment. }\end{array}$ & $\begin{array}{l}\text { Thoughtful investment in capacity- } \\
\text { building for public participation of } \\
\text { resource users through double-loop } \\
\text { learning can substantially improve } \\
\text { their contributions to existing } \\
\text { democratic processes. It increases } \\
\text { public faith in existing government } \\
\text { structures and seems likely to reduce } \\
\text { the threat of polarization. }\end{array}$ & \\
\hline 31 & $\begin{array}{l}\text { Leach et al. } \\
\text { (2013) }\end{array}$ & Testing hypothesis & $\begin{array}{l}\text { Interviews (61), } \\
\text { Survey (123) in } 10 \\
\text { water partnerships in } \\
\text { the USA }\end{array}$ & $\begin{array}{l}\text { Partnership Traits: diversity of participants, procedural } \\
\text { fairness, level of scientific certainty, trustworthiness of } \\
\text { other participants } \\
\text { Individual Traits of the Learner: duration of participation, } \\
\text { competence in science or technology, preferences for } \\
\text { consensus-based decision making, demographics }\end{array}$ & $\begin{array}{l}\text { Belief change as a product of } \\
\text { knowledge acquisition and knowledge } \\
\text { acquisition as a product of partnership } \\
\text { traits and traits of the individual } \\
\text { learner. we conclude that the roles of } \\
\text { science and expertise depend on the } \\
\text { context of a particular partnership to a }\end{array}$ & $\begin{array}{l}\text { USA and } \\
\text { water, self- } \\
\text { assessment }\end{array}$ \\
\hline
\end{tabular}




\begin{tabular}{|c|c|c|c|c|c|c|}
\hline No & Reference & Purpose of the Study & Methods & Factors Influencing Social Learning & $\begin{array}{c}\text { Conclusions } \\
\end{array}$ & Limitations \\
\hline & & & & & $\begin{array}{l}\text { greater extent than other variables, } \\
\text { such as trust and fairness, which have } \\
\text { consistently salutary effects on } \\
\text { collaboration in study after study }\end{array}$ & \\
\hline 32 & $\begin{array}{l}\text { Baird et al. } \\
\text { (2014) }\end{array}$ & $\begin{array}{l}\text { To advance and } \\
\text { operationalize a typology } \\
\text { of learning in an } \\
\text { environmental governance } \\
\text { context, and examined if a } \\
\text { participatory decision- } \\
\text { making process (adaptive } \\
\text { co-management) for } \\
\text { climate change adaptation } \\
\text { fostered learning. }\end{array}$ & $\begin{array}{l}\text { 'Case study' Canada, } \\
\text { experimental } \\
\text { participation process, } \\
\text { ex-ante and ex-post } \\
\text { data collection }\end{array}$ & $\begin{array}{l}\text { Involvement intensity: low activity level (participation in } \\
\text { three or fewer meetings) and high activity level } \\
\text { (participation in more than three meetings) }\end{array}$ & & Experiment \\
\hline 33 & $\begin{array}{l}\text { Koontz } \\
(2014)\end{array}$ & $\begin{array}{l}\text { Examine how participatory } \\
\text { processes can be designed } \\
\text { to promote social learning }\end{array}$ & $\begin{array}{l}\text { Comparison of two } \\
\text { case studies in the } \\
\text { USA and Germany, } \\
\text { water }\end{array}$ & $\begin{array}{l}\text { inclusiveness (variety of participants with diverse } \\
\text { viewpoints); extended engagement (multiple } \\
\text { opportunities to engage over time); information exchange } \\
\text { (opportunities to exchange information); opportunities for } \\
\text { interaction (dialogue among participants); process control } \\
\text { (participants' ability to set the agenda and procedures); } \\
\text { and process equity (individual efficacy and being taken } \\
\text { seriously by others) }\end{array}$ & & $\begin{array}{l}\text { Intensive } \\
\text { dialogue } \\
\text { processes } \\
\text { over time, } \\
\text { only two } \\
\text { states }\end{array}$ \\
\hline 34 & $\begin{array}{l}\text { van der Wal } \\
\text { et al. (2014) }\end{array}$ & $\begin{array}{l}\text { Present a simple and } \\
\text { flexible method to } \\
\text { measure social learning, } \\
\text { whether it has occurred } \\
\text { and to what extent, among } \\
\text { stakeholders in natural } \\
\text { resource management }\end{array}$ & $\begin{array}{l}\text { Case studies, game } \\
\text { sessions, } \\
\text { questionnaires, } \\
\text { Dutch river } \\
\text { management project } \\
\text { and adaptation } \\
\text { strategies for } \\
\text { agricultural land use } \\
\end{array}$ & $\begin{array}{l}\text { Case-related Factors: urgency, convergence of interests, } \\
\text { mutually felt positive interdependence and trust, limited } \\
\text { risk and balance of power among the stakeholders, } \\
\text { supportive institutional context } \\
\text { Process-related Factors: balanced stakeholder selection, } \\
\text { effective leadership or facilitation, space for reflection, } \\
\text { safe and informal environment, transparency }\end{array}$ & $\begin{array}{l}\text { Reflection about the method applied } \\
\text { to measure social learning }\end{array}$ & $\begin{array}{l}\text { Experiment } \\
\text {, no } \\
\text { discussion } \\
\text { about } \\
\text { context }\end{array}$ \\
\hline 35 & $\begin{array}{l}\text { Vinke-de } \\
\text { Kruijf et al. } \\
\text { (2014) }\end{array}$ & $\begin{array}{l}\text { What are the nature and } \\
\text { effects of social learning? } \\
\text { To what extent does social } \\
\text { learning contribute to } \\
\text { further collaboration in } \\
\text { international collaborative } \\
\text { settings? }\end{array}$ & $\begin{array}{l}\text { Case study, } \\
\text { international water } \\
\text { management project, } \\
\text { documentation, } \\
\text { interviews, and } \\
\text { observations }\end{array}$ & $\begin{array}{l}\text { Motivations and a joint motivating goal, cognitions and } \\
\text { negotiated knowledge, resources and pooling of } \\
\text { resources, relations and trust }\end{array}$ & $\begin{array}{l}\text { Learning differs between external and } \\
\text { local actors and between individuals. } \\
\text { Learning can have positive and } \\
\text { negative effects. }\end{array}$ & $\begin{array}{l}\text { Quantitativ } \\
\text { e data, } \\
\text { single case, } \\
\text { barriers } \\
\text { such as } \\
\text { language } \\
\text { and culture } \\
\text { are not } \\
\text { considered }\end{array}$ \\
\hline 36 & $\begin{array}{l}\text { Egunyu and } \\
\text { Reed (2015) }\end{array}$ & $\begin{array}{l}\text { To better understand how } \\
\text { gender affects social }\end{array}$ & $\begin{array}{l}\text { Case study, } \\
\text { interviews, Canada }\end{array}$ & Gender, cultural aspects & $\begin{array}{l}\text { Gender plays a role in access to and } \\
\text { outcomes of participation and social }\end{array}$ & $\begin{array}{l}\text { Focus on } \\
\text { Gender, }\end{array}$ \\
\hline
\end{tabular}




\begin{tabular}{|c|c|c|c|c|c|c|}
\hline No & Reference & Purpose of the Study & Methods & Factors Influencing Social Learning & $\begin{array}{c}\text { Conclusions } \\
\end{array}$ & Limitations \\
\hline & & $\begin{array}{l}\text { learning and collaborative } \\
\text { forest governance in } \\
\text { forest-based communities }\end{array}$ & and Uganda & & $\begin{array}{l}\text { learning in collaborative forest } \\
\text { governance. }\end{array}$ & $\begin{array}{l}\text { only two } \\
\text { cases }\end{array}$ \\
\hline 37 & $\begin{array}{l}\text { Elbakidze et } \\
\text { al. (2015) }\end{array}$ & $\begin{array}{l}\text { To identify to what extend } \\
\text { comprehensive planning is } \\
\text { characterized as a } \\
\text { collaborative learning } \\
\text { process }\end{array}$ & $\begin{array}{l}\text { Case study, } 36 \text { semi- } \\
\text { structured } \\
\text { interviews, spatial } \\
\text { planning Sweden }\end{array}$ & $\begin{array}{l}\text { A high level of stakeholder participation in the planning } \\
\text { process; participation in activities that promote new ideas } \\
\text { and learning among stakeholders in a municipality; } \\
\text { sufficient planning capacity of organisations and } \\
\text { institutions responsible for development, preparation and } \\
\text { delivery of strategic spatial plans; a confluence of views as } \\
\text { regards desirable solutions in strategic territorial } \\
\text { development; collaborative assessment and adaptation of } \\
\text { strategic spatial plans; implementation of the plan; } \\
\text { collaborative assessment of plan outcomes }\end{array}$ & $\begin{array}{l}\text { to encourage collaborative learning } \\
\text { there is a need for arenas allowing and } \\
\text { promoting stakeholder activity, } \\
\text { participation and inclusion that } \\
\text { represents all societal sectors at } \\
\text { multiple levels, as well as interaction } \\
\text { between both bottom-up and top- } \\
\text { down approaches }\end{array}$ & $\begin{array}{l}\text { Limited to } \\
\text { four } \\
\text { stakeholder } \\
\text { groups }\end{array}$ \\
\hline 38 & $\begin{array}{l}\text { Natarajan } \\
(2017)\end{array}$ & $\begin{array}{l}\text { How does learning with } \\
\text { communities reframe } \\
\text { spatial knowledge? }\end{array}$ & $\begin{array}{l}\text { Case study, United } \\
\text { Kingdom }\end{array}$ & $\begin{array}{l}\text { Local knowledge, process knowledge, trust building, } \\
\text { shared concerns, ongoing support, encouragement and } \\
\text { validation }\end{array}$ & $\begin{array}{l}\text { Low knowledge of planning processes } \\
\text { was not a barrier to communication } \\
\text { with local people, but low confidence } \\
\text { threatened to be. }\end{array}$ & $\begin{array}{l}\text { Single case } \\
\text { study, face- } \\
\text { to-face } \\
\text { dialogue }\end{array}$ \\
\hline 39 & $\begin{array}{l}\text { Schauppenle } \\
\text { hner-Kloyber } \\
\text { and Penker } \\
\text { (2015) }\end{array}$ & $\begin{array}{l}\text { How to effectively } \\
\text { promote social learning } \\
\text { and capacity building for } \\
\text { self-organised action } \\
\text { beyond project end }\end{array}$ & $\begin{array}{l}\text { Case study, } \\
\text { documents, } \\
\text { observation, survey, } \\
\text { urban development, } \\
\text { Austria } \\
\end{array}$ & Stages of group processes, facilitation, & $\begin{array}{l}\text { Shifting the focus from 'output } \\
\text { thinking' to 'process thinking' }\end{array}$ & $\begin{array}{l}\text { Focusing on } \\
\text { TDR, single } \\
\text { case study, } \\
\text { experiment } \\
\text { al character } \\
\end{array}$ \\
\hline 40 & $\begin{array}{l}\text { Beers et al. } \\
(2016)\end{array}$ & $\begin{array}{l}\text { To develop a new } \\
\text { theoretical approach that } \\
\text { takes on an integrative } \\
\text { perspective on learning, } \\
\text { and to operationalize that } \\
\text { into a framework and } \\
\text { explore it empirically. } \\
\end{array}$ & $\begin{array}{l}\text { Case study, Reflexive } \\
\text { Monitoring in Action } \\
\text { (action research) }\end{array}$ & $\begin{array}{l}\text { Different patterns of communicative interaction: } \\
\text { antithetic interaction, synthetic interaction, informing, } \\
\text { Word-of-Power, agenda wars, conflict }\end{array}$ & $\begin{array}{l}\text { Social learning can be regarded as } \\
\text { discursive interaction with learning } \\
\text { outcomes in terms of interwoven } \\
\text { knowledge, relations, and action and } \\
\text { that some interaction patterns are } \\
\text { more closely connected to social } \\
\text { learning than others. }\end{array}$ & $\begin{array}{l}\text { Single case } \\
\text { study, } \\
\text { expert } \\
\text { dialogue, } \\
\text { intensive } \\
\text { participatio } \\
\mathrm{n}\end{array}$ \\
\hline 41 & $\begin{array}{l}\text { Benson et al. } \\
(2016)\end{array}$ & $\begin{array}{l}\text { To what extend does } \\
\text { stakeholder participation } \\
\text { in environmental } \\
\text { management actually lead } \\
\text { to social learning? }\end{array}$ & $\begin{array}{l}\text { Case studies, } \\
\text { observation and } \\
\text { semi-structured } \\
\text { interviews, flood risk } \\
\text { management, UK } \\
\end{array}$ & $\begin{array}{l}\text { Individual interest and capacity to learn from } \\
\text { participation, knowledge about topic, institutional } \\
\text { structures }\end{array}$ & $\begin{array}{l}\text { while individual 'surface' change was } \\
\text { widespread amongst Committee } \\
\text { members, 'deeper' ontological } \\
\text { changes were less evident }\end{array}$ & $\begin{array}{l}\text { Only UK, } \\
\text { focus on } \\
\text { learning } \\
\text { products }\end{array}$ \\
\hline 42 & $\begin{array}{l}\text { Medema et } \\
\text { al. (2016) }\end{array}$ & $\begin{array}{l}\text { Exploring social learning in } \\
\text { transboundary water } \\
\text { resource management }\end{array}$ & $\begin{array}{l}\text { Case study, river } \\
\text { basin management } \\
\text { Canada, } 10 \text { semi- } \\
\text { structured interviews }\end{array}$ & $\begin{array}{l}\text { Characteristics of stakeholders and institutional setting, } \\
\text { stakeholder interactions and the way this engagement } \\
\text { process is organized; quality of stakeholder relationships }\end{array}$ & $\begin{array}{l}\text { Social learning was the exception } \\
\text { rather than the rule, probably due to } \\
\text { low levels of collaboration. }\end{array}$ & $\begin{array}{l}\text { Very view } \\
\text { interviews, } \\
\text { case study }\end{array}$ \\
\hline 43 & $\begin{array}{l}\text { Salvini et al. } \\
\text { (2016) }\end{array}$ & $\begin{array}{l}\text { Explored application of an } \\
\text { role planning game to } \\
\text { stimulate exchanges of }\end{array}$ & $\begin{array}{l}\text { Role playing } \\
\text { experiment with } \\
\text { farmers in Brazil, pre- }\end{array}$ & & $\begin{array}{l}\text { The informal and experimental design } \\
\text { foster different elements of learning. }\end{array}$ & Experiment \\
\hline
\end{tabular}




\begin{tabular}{|c|c|c|c|c|c|c|}
\hline No & Reference & Purpose of the Study & \begin{tabular}{|c|} 
Methods \\
\end{tabular} & Factors Influencing Social Learning & Conclusions & Limitations \\
\hline & & $\begin{array}{l}\text { knowledge and to facilitate } \\
\text { collective decision-making } \\
\text { and negotiation }\end{array}$ & $\begin{array}{l}\text { and post interviews } \\
\text { (42 interviews total) }\end{array}$ & & & \\
\hline 44 & $\begin{array}{l}\text { Westberg } \\
\text { and Polk } \\
(2016)\end{array}$ & $\begin{array}{l}\text { Analyse the } \\
\text { "transferability" of } \\
\text { knowledge generated in TD } \\
\text { research settings from a } \\
\text { practice-based approach }\end{array}$ & $\begin{array}{l}\text { Case studies: } \\
\text { describe and analyse } \\
\text { three TD projects }\end{array}$ & $\begin{array}{l}\text { Important to analyse how the members of the TD } \\
\text { practices themselves interpret what they are meant to } \\
\text { accomplish. Create spaces for reflection and create } \\
\text { opportunities for learning on a meta-level }\end{array}$ & $\begin{array}{l}\text { Focusing on developing joint } \\
\text { understandings that were based on } \\
\text { their different perspectives of the } \\
\text { governance processes under study } \\
\text { helped to generate relevant } \\
\text { knowledge. }\end{array}$ & $\begin{array}{l}\text { Focused on } \\
\text { TD }\end{array}$ \\
\hline 45 & $\begin{array}{l}\text { Berman } \\
(2017)\end{array}$ & $\begin{array}{l}\text { Which participatory } \\
\text { practices are most } \\
\text { efficacious capturing local } \\
\text { knowledge and } \\
\text { incorporating it into plans? }\end{array}$ & $\begin{array}{l}\text { Case studies, } \\
\text { interviews, } \\
\text { document analysis, } \\
\text { spatial planning, } \\
\text { Israel }\end{array}$ & Participatory format: unilateral, collaborative & $\begin{array}{l}\text { Unidirectional participatory } \\
\text { procedures do not capture genuine } \\
\text { local knowledge and do not } \\
\text { incorporate local knowledge into } \\
\text { plans. }\end{array}$ & $\begin{array}{l}\text { Case } \\
\text { studies, } \\
\text { focusing on } \\
\text { a specific } \\
\text { learning } \\
\text { product }\end{array}$ \\
\hline 46 & $\begin{array}{l}\text { de Vries et al. } \\
\text { (2017) }\end{array}$ & $\begin{array}{l}\text { how trust influences } \\
\text { knowledge sharing and } \\
\text { how knowledge sharing } \\
\text { influences trust }\end{array}$ & $\begin{array}{l}\text { Worksop evaluation, } \\
\text { water governance, } \\
\text { Sweden }\end{array}$ & Trust & $\begin{array}{l}\text { The role of trust is far from static, } \\
\text { supporting the idea that the } \\
\text { production, sharing, and use of } \\
\text { knowledge is a dynamic process. It also } \\
\text { shows that trust is not necessarily } \\
\text { bound to long processes as often } \\
\text { stated. }\end{array}$ & Experiment \\
\hline 47 & $\begin{array}{l}\text { Roldán } \\
\text { (2017) }\end{array}$ & $\begin{array}{l}\text { It aims at opening up the } \\
\text { debate on the assumption } \\
\text { that stakeholder } \\
\text { participation in NRM } \\
\text { produces similar outcomes } \\
\text { independently of the } \\
\text { political context where it is } \\
\text { embedded by identifying } \\
\text { similarities and differences } \\
\text { in one outcome: } \\
\text { multidirectional learning. }\end{array}$ & $\begin{array}{l}\text { Survey, UNESCO } \\
\text { biosphere reserves }\end{array}$ & Political regime: democratic, nondemocratic & $\begin{array}{l}\text { Although learning can occur in both } \\
\text { regimes, benefits may be more limited } \\
\text { in non-democracies as they seem to } \\
\text { take less advantage of the diversity of } \\
\text { knowledge that including multiple } \\
\text { stakeholders in participation can } \\
\text { provide. }\end{array}$ & $\begin{array}{l}\text { Self- } \\
\text { assessment } \\
\text { considerati } \\
\text { on of very } \\
\text { limited } \\
\text { factors } \\
\text { influencing } \\
\text { learning }\end{array}$ \\
\hline 48 & $\begin{array}{l}\text { Heikkila and } \\
\text { Gerlak (2018) }\end{array}$ & $\begin{array}{l}\text { How the design of rules of } \\
\text { a governance process } \\
\text { conditions opportunities } \\
\text { for learning }\end{array}$ & $\begin{array}{l}\text { Comparison of five } \\
\text { empirical studies }\end{array}$ & $\begin{array}{l}\text { IAD framework rules: boundary, position, choice, } \\
\text { information, aggregation, payoff, and scope rules }\end{array}$ & $\begin{array}{l}\text { Diverse stakeholder participation and } \\
\text { integration of various knowledge types } \\
\text { foster learning. Also }\end{array}$ & $\begin{array}{l}\text { No direct } \\
\text { measureme } \\
\text { nt }\end{array}$ \\
\hline
\end{tabular}


Armitage, D., M. Marschke, and R. Plummer. 2008. Adaptive co-management and the paradox of learning. Global Environmental Change 18:86-98.

Baird, J., R. Plummer, C. Haug, and D. Huitema. 2014. Learning effects of interactive decision-making processes for climate change adaptation. Global Environmental Change 27:51-63.

Beers, P. J., B. v. Mierlo, and A.-C. Hoes. 2016. Toward an Integrative Perspective on Social Learning in System Innovation Initiatives. Ecology and Society 21:33.

Beierle, T. C. 2002. The quality of stakeholder-based decisions. Risk Analysis 22:739-749.

Beierle, T. C., and J. Cayford. 2002. Democracy in practice: public participation in environmental decisions. Resources for the Future, Washington, DC.

Beierle, T. C., and D. M. Konisky. 2000. Values, conflict, and trust in participatory environmental planning. Journal of Policy Analysis and Management 19:587-602.

Benson, D., I. Lorenzoni, and H. Cook. 2016. Evaluating social learning in England flood risk management: An 'individual-community interaction' perspective. Environmental Science \& Policy 55:326-334.

Berman, T. 2017. Public participation as a tool for integrating local knowledge into spatial planning. Springer International Publishing.

Borowski, I., J. P. Le Bourhis, C. Pahl-Wostl, and B. Barraque. 2008. Spatial Misfit in Participatory River Basin Management: Effects on Social Learning, a Comparative Analysis of German and French Case Studies. Ecology and Society 13:22.

Brewer, J. F. 2013. From experiential knowledge to public participation: social learning at the community fisheries action roundtable. Environmental Management 52:321-334.

Brown, V. A., M. Keen, and R. Dyball. 2005. Lessons from the Past, Learning for the Future. Pages 247-264 in M. Keen, V. A. Brown, and R. Dyball, editors. Social Learning in Environmental Management. Earthscan, London.

Brummel, R. F., K. C. Nelson, S. G. Souter, P. J. Jakes, and D. R. Williams. 2010. Social learning in a policy-mandated collaboration: community wildfire protection planning in the eastern United States. Journal of Environmental Planning and Management 53:681-699.

Burgess, J., and J. Clark. 2009. Practitioner Evaluations of Participatory Processes in Environmental Decision Making. Pages 159-190 in N. Adger and A. Jordan, editors. Governing Sustainability. Cambridge University Press, Cambridge, UK ; New York.

Carr, G., G. Blöschl, and D. P. Loucks. 2012. Evaluating participation in water resource management: A review. Water Resources Research 48.

Coenen, F. H. J. M., D. Huitema, and L. J. O'Toole. 1998. Participation and Envrionmental Decsion Quality: an Assessment. Pages $307-326$ in F. H. J. M. Coenen, D. Huitema, and L. J. O'Toole, editors. Participation and the Quality of Envrionmental Decision Making. Kluwer Academic Publishers, Dodrecht; Norwell.

Crona, B. I., and J. N. Parker. 2012. Learning in Support of Governance: Theories, Methods, and a Framework to Assess How Bridging Organizations Contribute to Adaptive Resource Governance. Ecology and Society 17:32.

Cundill, G. 2010. Monitoring Social Learning Processes in Adaptive Comanagement: Three Case Studies from South Africa. Ecology and Society 15:28. Cuppen, E. 2012. A quasi-experimental evaluation of learning in a stakeholder dialogue on bio-energy. Research Policy 41:624-637.

Cuppen, E. 2018. The value of social conflicts. Critiquing invited participation in energy projects. Energy Research \& Social Science 38:28-32.

de Vries, J., S. van Bommel, C. Blackmore, and Y. Asano. 2017. Where There Is No History: How to Create Trust and Connection in Learning for Transformation in Water Governance. Water 9:130.

Duram, L. A., and K. G. Brown. 1999. Assessing public participation in US watershed planning initiatives. Society \& Natural Resources 12:455-467. 
Edelenbos, J., A. van Buuren, and N. van Schie. 2011. Co-producing knowledge: joint knowledge production between experts, bureaucrats and stakeholders in Dutch water management projects. Environmental Science \& Policy 14:675-684.

Egunyu, F., and M. G. Reed. 2015. Social learning by whom? Assessing gendered opportunities for participation and social learning in collaborative forest governance. Ecology and Society 20:44.

Elbakidze, M., L. Dawson, K. Andersson, R. Axelsson, P. Angelstam, I. Stjernquist, S. Teitelbaum, P. Schlyter, and C. Thellbro. 2015. Is spatial planning a collaborative learning process? A case study from a rural-urban gradient in Sweden. Land Use Policy 48:270-285.

Ernst, A., A. Fischer-Hotzel, and D. Schumann. 2017. Transforming knowledge for sustainability: Insights from an inclusive science-practice dialogue on low-carbon society in Germany. Energy Research \& Social Science 29:23-35.

Fiorino, D. J. 1990. Citizen Participation and Environmental Risk: A Survey of Institutional Mechanisms. Science, Technology, \& Human Values 15:226243.

Garmendia, E., and S. Stagl. 2010. Public participation for sustainability and social learning: Concepts and lessons from three case studies in Europe. Ecological Economics 69:1712-1722.

Gerlak, A. K., and T. Heikkila. 2011. Building a Theory of Learning in Collaboratives: Evidence from the Everglades Restoration Program. Journal of Public Administration Research and Theory 21:619-644.

Gohl, C., and J. Wüst. 2008. Beteiligung braucht Wissen - Beteiligung schafft Wissen. Pages 259-280 in A. Vetter, editor. Erfolgsbedingungen lokaler Bürgerbeteiligung. VS Verlang für Sozialwissenschaften, Wiesbaden.

Heikkila, T., and A. K. Gerlak. 2018. Working on learning: how the institutional rules of environmental governance matter. Journal of Environmental Planning and Management:1-18.

Hoverman, S., H. Ross, T. Chan, and B. Powell. 2011. Social Learning through Participatory Integrated Catchment Risk Assessment in the Solomon Islands. Ecology and Society 16:17.

Huitema, D., C. Cornelisse, and B. Ottow. 2010. Is the Jury Still Out? Toward Greater Insight in Policy Learning in Participatory Decision Processesthe Case of Dutch Citizens' Juries on Water Management in the Rhine Basin. Ecology and Society 15:16.

Jiggins, J., E. van Slobbe, and N. Roling. 2007. The organisation of social learning in response to perceptions of crisis in the water sector of The Netherlands. Environmental Science \& Policy 10:526-536.

Knoepfel, P., and I. Kissling-Näf. 1998. Social learning in policy networks. Policy and politics 26:343-367.

Koontz, T. M. 2014. Social learning in collaborative watershed planning: the importance of process control and efficacy. Journal of Environmental Planning and Management 57:1572-1593.

Kumler, L. M., and M. C. Lemos. 2008. Managing Waters of the Paraiba do Sul River Basin, Brazil: a Case Study in Institutional Change and Social Learning. Ecology and Society 13:13.

Leach, W. D., and N. Pelkey. 2001. Making Watershed Partnerships Work: A Review of the Empirical Literature. JOURNAL OF WATER RESOURCES PLANNING AND MANAGEMENT 127:378-385.

Leach, W. D., N. W. Pelkey, and P. A. Sabatier. 2002. Stakeholder partnerships as collaborative policymaking: Evaluation criteria applied to watershed management in California and Washington. Journal of Policy Analysis and Management 21:645-670.

Leach, W. D., C. M. Weible, S. R. Vince, S. N. Siddiki, and J. C. Calanni. 2013. Fostering Learning through Collaboration: Knowledge Acquisition and Belief Change in Marine Aquaculture Partnerships. Journal of Public Administration Research and Theory 24:591-622. 
Medema, W., A. Furber, J. Adamowski, Q. Zhou, and I. Mayer. 2016. Exploring the Potential Impact of Serious Games on Social Learning and Stakeholder Collaborations for Transboundary Watershed Management of the St. Lawrence River Basin. Water 8:175.

Mostert, E., C. Pahl-Wostl, Y. Rees, B. Searle, D. Tabara, and J. Tippett. 2007. Social Learning in European River-Basin Management: Barriers and Fostering Mechanisms from 10 River Basins. Ecology and Society 12:19.

Muro, M., and P. Jeffrey. 2012. Time to Talk? How the Structure of Dialog Processes Shapes Stakeholder Learning in Participatory Water Resources Management. Ecology and Society 17:3.

Natarajan, L. 2017. Socio-spatial learning: A case study of community knowledge in participatory spatial planning. Progress in Planning 111:1-23.

Newig, J. 2007. Does public participation in environmental decisions lead to improved environmental quality?: towards an analytical framework. Communication, Cooperation, Participation (International Journal of Sustainability Communication) 1:51-71.

Newig, J., K. Kuhn, and H. Heinrichs. 2011. Nachhaltige Entwicklung durch gesellschaftliche Partizipation und Kooperation? - eine kritische Revision zentraler Theorien und Konzepte. Pages 27-45 in H. Heinrichs, K. Kuhn, and J. Newig, editors. Nachhaltige Gesellschaft: Welche Rolle für Partizipation und Kooperation? VS Verlag für Sozialwissenschaften, Wiesbaden.

Pahl-Wostl, C., M. Craps, A. Dewulf, E. Mostert, D. Tabara, and T. Taillieu. 2007. Social learning and water resources management. Ecology and Society 12:5.

Palm, J., and J. Thoresson. 2014. Strategies and Implications for Network Participation in Regional Climate and Energy Planning. Journal of Environmental Policy \& Planning 16:3-19.

Parés, M., Q. Brugué, J. Espluga, J. Miralles, and A. Ballester. 2015. The Strengths and Weaknesses of Deliberation on River Basin Management Planning: Analysing the water framework directive implementation in Catalonia (Spain). Environmental Policy and Governance 25:97-110.

Peterson, N. D., K. Broad, B. Orlove, C. Roncoli, R. Taddei, and M.-A. Velez. 2010. Participatory processes and climate forecast use: Socio-cultural context, discussion, and consensus. Climate and Development 2:14-29.

Petts, J. 2006. Managing Public Engagement to Optimize Learning: Reflections from Urban River Restoration. Human Ecology Review 13:172-181.

Pohl, C., S. Rist, A. Zimmermann, P. Fry, G. S. Gurung, F. Schneider, C. I. Speranza, B. Kiteme, S. Boillat, E. Serrano, G. H. Hadorn, and U. Wiesmann. 2010. Researchers' roles in knowledge co-production: experience from sustainability research in Kenya, Switzerland, Bolivia and Nepal. Science and Public Policy 37:267-281.

Reed, M. S. 2008. Stakeholder participation for environmental management: A literature review. Biological Conservation 141:2417-2431.

Roldán, A. M. 2017. Political Regime and Learning Outcomes of Stakeholder Participation: Cross-National Study of 81 Biosphere Reserves. Sustainability 9:553.

Rowe, G., and L. J. Frewer. 2000. Public Participation Methods: A Framework for Evaluation. Science Technology \& Human Values 25:3-29.

Salvini, G., A. van Paassen, A. Ligtenberg, G. C. Carrero, and A. K. Bregt. 2016. A role-playing game as a tool to facilitate social learning and collective action towards Climate Smart Agriculture: Lessons learned from Apuí, Brazil. Environmental Science \& Policy 63:113-121.

Schauppenlehner-Kloyber, E., and M. Penker. 2015. Managing group processes in transdisciplinary future studies: How to facilitate social learning and capacity building for self-organised action towards sustainable urban development? Futures 65:57-71.

Schroeter, R., O. Scheel, O. Renn, and P.-J. Schweizer. 2016. Testing the value of public participation in Germany: Theory, operationalization and a case study on the evaluation of participation. Energy Research \& Social Science 13:116-125. 
Schusler, T. M., D. J. Decker, and M. J. Pfeffer. 2003. Social Learning for Collaborative Natural Resource Management. Society \& Natural Resources 16:309-326.

Schweizer, P.-J., O. Renn, W. Köck, J. Bovet, C. Benighaus, O. Scheel, and R. Schröter. 2016. Public participation for infrastructure planning in the context of the German “Energiewende". Utilities Policy 43:206-209.

Squires, H., and O. Renn. 2011. Can Participatory Modelling Support Social Learning in Marine Fisheries? Reflections from the Invest in Fish South West Project. Environmental Policy and Governance 21:403-416.

Tippett, J., B. Searle, C. Pahl-Wostl, and Y. Rees. 2005. Social learning in public participation in river basin management-early findings from HarmoniCOP European case studies. Environmental Science \& Policy 8:287-299.

Van Bommel, S., N. Röling, N. Aarts, and E. Turnhout. 2009. Social learning for solving complex problems: a promising solution or wishful thinking? A case study of multi-actor negotiation for the integrated management and sustainable use of the Drentsche Aa area in the Netherlands. Environmental Policy and Governance 19:400-412.

van de Kerkhof, M., and A. Wieczorek. 2005. Learning and Stakeholder Participation in Transition Processes towards Sustainability: Methodological Considerations. Technological Forecasting and Social Change 72:733-747.

van der Wal, M., J. De Kraker, A. Offermans, C. Kroeze, P. A. Kirschner, and M. van Ittersum. 2014. Measuring Social Learning in Participatory Approaches to Natural Resource Management. Environmental Policy and Governance 24:1-15.

Vinke-de Kruijf, J., H. Bressers, and D. C. M. Augustijn. 2014. How social learning influences further collaboration: experiences from an international collaborative water project. Ecology and Society 19.

Webler, T. 1995. "Rigth" Discourse in Citizen Participation: An evaluative Yardstick.in O. Renn, T. Webler, and P. Wiedemann, editors. Fairness and Competence in Citizen participation. Kluwer Academic Publishers, Dordrecht Norwell.

Webler, T., H. Kastenholz, and O. Renn. 1995. Public Participation in Impact Assessment: A Social Learning Perspective. Environmental Impact Assessment Review 15:443-463.

Webler, T., and S. Tuler. 2000. Fairness and Competence in Citizen Participation: Theoretical Reflections from a Case Study. Administration \& Society 32:566-595.

Westberg, L., and M. Polk. 2016. The role of learning in transdisciplinary research: moving from a normative concept to an analytical tool through a practice-based approach. Sustainability Science 11:385-397.

Wiek, A. 2007. Challenges of transdisciplinary research as interactive knowledge generation - Experiences from transdisciplinary case study research. Gaia-Ecological Perspectives for Science and Society 16:52-57.

Wilner, K. B., M. Wiber, A. Charles, J. Kearney, M. Landry, and L. Wilson. 2012. Transformative learning for better resource management: the role of critical reflection. Journal of Environmental Planning and Management 55:1331-1347.

Yandle, T., N. Hajj, and R. Raciborski. 2011. The Goldilocks Solution: Exploring the Relationship between Trust and Participation in Resource Management within the New Zealand Commercial Rock Lobster Fishery. Policy Studies Journal 39:631-658. 